In cooperation with the State of Washington Military Department Emergency Management Division

\title{
Community Exposure to Lahar Hazards from Mount Rainier, Washington
}

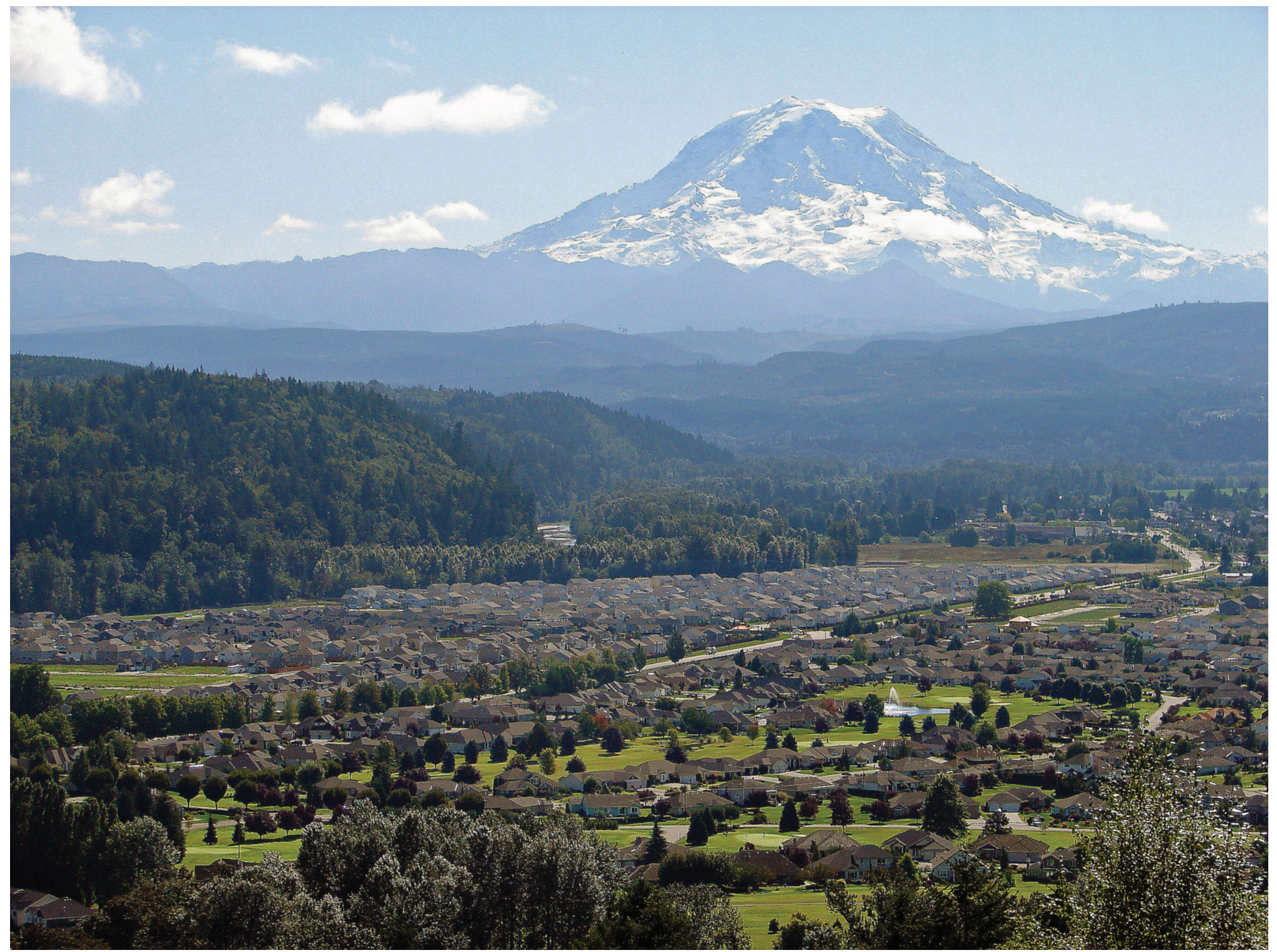

Scientific Investigations Report 2009-5211 
FRONT COVER — Photograph of Mount Rainier and Orting, Washington, as seen from a ridge to the west. Orting is one of many communities that are in lahar-prone areas below the flanks of Mount Rainier. (USGS photograph taken on September 8, 2009, by Nathan Wood.) 


\section{Community Exposure to Lahar Hazards from Mount Rainier, Washington}

By Nathan J. Wood and Christopher E. Soulard

Scientific Investigations Report 2009-5211 


\section{U.S. Department of the Interior \\ KEN SALAZAR, Secretary \\ U.S. Geological Survey \\ Suzette M. Kimball, Acting Director}

\section{U.S. Geological Survey, Reston, Virginia: 2009}

This report and any updates to it are available online at:

http://pubs.usgs.gov/sir/2009/5211/

For more information on the USGS - the Federal source for science about the Earth, its natural and living resources, natural hazards, and the environment, visit http://www.usgs.gov or call 1-888-ASK-USGS

For an overview of USGS information products, including maps, imagery, and publications, visit http://www.usgs.gov/pubprod

To order this and other USGS information products, visit http://store.usgs.gov

Any use of trade, product, or firm names is for descriptive purposes only and does not imply endorsement by the U.S. Government.

Although this report is in the public domain, permission must be secured from the individual copyright owners to reproduce any copyrighted materials contained within this report.

Suggested citation:

Wood, N. J., and Soulard, C. E., 2009, Community exposure to lahar hazards from Mount Rainier, Washington: U.S Geological Survey Scientific Investigations Report 2009-5211, 26 p. 


\section{Contents}

Abstract
Introduction.
Purpose and Scope
Study Area
Variations in Community Exposure
Land Cover
Critical and Essential Facilities and Infrastructure
Composite Indices of Community Exposure
Conclusions.
Acknowledgments
References Cited.

\section{Figures}

1. Map showing counties, incorporated cities, and census-designated places within a lahar-hazard zone on and near Mount Rainier

2. Map of a lahar-hazard zone associated with Mount Rainier and land-cover data from the 2001 National Land Cover Database................................................5

3. Distribution of land-cover classes in the selected Mount Rainier lahar-hazard zone................6

4. Amount $(A)$ and percentage $(B)$ of developed land in the selected lahar-hazard zone for communities downstream of Mount Rainier ..................................................................7

5. Number $(A)$ and percentage $(B)$ of residents in the selected lahar-hazard zone for communities downstream of Mount Rainier...........................................................9

6. Percentages of households in the selected Mount Rainier lahar-hazard zone that are $(A)$ renter-occupied households and $(B)$ female-headed households with children and no spouse present.

7. Difference between 1990 and 2000 in the number $(A)$ and percentage $(B)$ of residents in the selected Mount Rainier lahar-hazard zone

8. Number $(A)$ and percentage $(B)$ of employees in the selected lahar-hazard zone for communities downstream of Mount Rainier

9. Percentage of employees, by business sector, in the selected Mount Rainier lahar-hazard zone

10. Number of dependent-population facilities in the selected lahar-hazard zone for communities downstream of Mount Rainier.

11. Number of public venues in the selected lahar-hazard zone for communities downstream of Mount Rainier..

12. Amount $(A)$ and percentage $(B)$ of total parcel value in the selected lahar-hazard zone for communities downstream of Mount Rainier. 
13. Map of roads and railroads in the selected lahar-hazard zone on and near Mount Rainier

14. Comparison of normalized indices for the amount and percentage of community assets in lahar-prone areas for communities that include land in the selected Mount Rainier lahar-hazard zone .....

15. Sum of normalized amount and percentage indices for relative exposure to lahar hazard for communities with land in the selected Mount Rainier lahar-hazard zone.

\section{Tables}

1. Block-level demographic characteristics for residential populations in the selected lahar-hazard zone of Mount Rainier

2. Amount and percentage of economic assets in the selected lahar-hazard zone of Mount Rainier

3. Amount and percentage of dependent-population facilities in the selected lahar-hazard zone of Mount Rainier.

4. Amount and percentage of public venues in the selected lahar-hazard zone of Mount Rainier, Washington.

5. Amount and percentage of critical and essential facilities assets in the selected lahar-hazard zone of Mount Rainier, Washington

6. Composite amount and percentage values for communities in the selected lahar-hazard zone of Mount Rainier 


\title{
Community Exposure to Lahar Hazards from Mount Rainier, Washington
}

\author{
By Nathan J. Wood and Christopher E. Soulard
}

\section{Abstract}

Geologic evidence of past events and inundation modeling of potential events suggest that lahars associated with Mount Rainier, Washington, are significant threats to downstream development. To mitigate potential impacts of future lahars and educate at-risk populations, officials need to understand how communities are vulnerable to these fast-moving debris flows and which individuals and communities may need assistance in preparing for and responding to an event. To support local risk-reduction planning for future Mount Rainier lahars, this study documents the variations among communities in King, Lewis, Pierce, and Thurston Counties in the amount and types of developed land, human populations, economic assets, and critical facilities in a lahar-hazard zone. The lahar-hazard zone in this study is based on the behavior of the Electron Mudflow, a lahar that traveled along the Puyallup River approximately 500 years ago and was due to a slope failure on the west flank of Mount Rainier. This lahar-hazard zone contains 78,049 residents, of which 11 percent are more than 65 years in age, 21 percent do not live in cities or unincorporated towns, and 39 percent of the households are renter occupied. The lahar-hazard zone contains 59,678 employees (4 percent of the four-county labor force) at 3,890 businesses that generate $\$ 16$ billion in annual sales (4 and 7 percent, respectively, of totals in the four-county area) and tax parcels with a combined total value of $\$ 8.8$ billion ( 2 percent of the study-area total). Employees in the lahar-hazard zone are primarily in businesses related to manufacturing, retail trade, transportation and warehousing, wholesale trade, and construction. Key road and rail corridors for the region are in the lahar-hazard zone, which could result in significant indirect economic losses for businesses that rely on these networks, such as the Port of Tacoma. Although occupancy values are not known for each site, the lahar-hazard zone contains numerous dependent-population facilities (for example, schools and child day-care centers), public venues (for example, religious organizations and hotels), and critical facilities (for example, police and fire stations). The lahar-hazard zone also includes high-volume tourist sites, such as Mount Rainier National Park and the Puyallup Fairgrounds. Community exposure to lahars associated with Mount Rainier varies considerably among 27 communities and four counties - some may experience great losses that reflect only a small portion of their community and others may experience relatively small losses that devastate them. Among 27 communities, the City of Puyallup has the highest number of people and assets in the lahar-hazard zone, whereas the communities of Carbonado, Fife, Orting, and Sumner have the highest percentages of people and assets in this zone. Based on a composite index, the cities of Puyallup, Sumner, and Fife have the highest combinations of the number and percentage of people and assets in lahar-prone areas.

\section{Introduction}

Large, swift, and saturated debris flows originating on volcanoes (often referred to by the Indonesian term "lahars") are significant volcanic hazards because of the long distances that they can travel from their source, the high speed at which they travel, and their initiation with or without an eruption. In the 20th century, lahars throughout the world caused more than 30,000 deaths, made 93,000 individuals homeless, and otherwise affected 1,000,000 people (Witham, 2005). The majority of the deaths were from a single event - when lahars related to the 1985 eruption of Nevado del Ruiz volcano inundated the city of Armero, Columbia, and killed more than 23,000 people (Witham, 2005; Voight, 1990).

Mount Rainier, Washington (USA) (fig. 1) is an active volcano that is currently between eruptions, yet has generated at least 60 lahars of various sizes over the past 10,000 years and will likely produce more because of its steep slopes and the large volume of water stored in its 25 glaciers (Hoblitt and others, 1998; Vallance and others 2003; Walder and Driedger, 1994). Although most Mount Rainier hazards (for example, ballistic projectiles) extend only a few kilometers beyond the National Park boundaries (fig.1), past lahars have traveled tens of kilometers from the summit (Vallance and others, 2003). Increasing urbanization of the lowlands downstream of Mount Rainier makes them one of the areas in the United States most at risk from a lahar flow (Scott and Vallance, 1995). Of all Mount Rainier hazards, a lahar that reaches Puget Sound is the greatest threat to people downvalley of the volcano (Hoblitt and others, 1998).

During the past several thousand years, Mount Rainier lahars reached the Puget Sound lowlands on average at least 
once every 500 to 1,000 years, with the last significant event, the Electron Mudflow, occurring approximately 500 years ago (Hoblitt and others, 1998; Driedger and Scott, 2008). Smaller lahars that did not reach the lowlands occurred more frequently. Based on this record of past lahars, there is roughly a 1-in-10 chance of a lahar reaching areas of human development in the Puget Sound lowlands during an average human lifespan (Driedger and Scott, 2008). The great majority of previous lahars were initiated by the swift melting of snow and ice during volcanic eruptions. Such lahars in the future will be preceded by volcanic events that will warn of impending lahar activity. In addition to these meltwater-driven events, lahars can also be caused by landslides. Landslides can be triggered when magma intrudes into a volcano and destabilizes it, by large earthquakes, or by spontaneous slope failure of weak, chemically altered, clay-rich rock. Recent studies have shown that the Puyallup and, to a lesser extent, the Nisqually Valleys are the only areas on Mount Rainier prone to such events (Finn and others, 2001; Sisson and others, 2001). Regardless of whether lahars originate from landslides or by rapid production of meltwater, they hold the potential for affecting areas that have had significant human development during the past two centuries.

Estimated arrival times for life-threatening lahars from Mount Rainier that reach communities in the Puget Sound lowlands range from tens of minutes (for example, Carbonado) to almost two hours (for example, Tacoma) (Pierson, 1998; Pierce County GIS Data Express, 2009). Therefore, if a lahar occurs, at-risk populations will have little time to take protective actions and seek higher ground out of harm's way. Efforts to reduce potential loss of life from Mount Rainier lahars have focused on determining where lahar inundation is possible (Hoblitt and others, 1998; Schilling and others, 2008), developing detection and warning systems in several river valleys to enable evacuations, coordinating responses among multiple jurisdictions and agencies (Pierce County Department of Emergency Management, 2008) and educating at-risk populations on the potential for lahars and how to evacuate lahar-prone areas if a lahar is detected upstream (Driedger and others, 1998; Driedger and Scott, 2002; Driedger and others, 2005; Driedger and Scott, 2008).

Although much has been done to develop warning systems and awareness programs for lahar hazards associated with Mount Rainier (as well as for volcanic hazards at other U.S. volcanoes), less has been done to understand societal vulnerability to these hazards, specifically the potential impacts on people and infrastructure (Aster and others, 2007). Vulnerability is often described in terms of the exposure, sensitivity, and adaptive capacity of a community and its assets to a hazard (Turner and others, 2003; Polsky and others, 2007) and takes into account the societal conditions in and around hazard-prone areas, such as land use, structure types, demographic patterns, economic conditions, and sociopolitical context (Wisner and others, 2004). A lahar is the physical process that damages buildings and injures people, but the extent of these losses is determined by the cumulative choices that communities have made and will make with regard to their use of lahar-prone land and their willingness to develop risk-reduction strategies (Mileti, 1999; Wisner and others, 2004). Understanding societal vulnerability to lahars helps officials to determine potential risk-reduction strategies (for example, changes in land use or structural mitigation), to tailor the format and delivery of education efforts to reach different populations (for example, residents or tourists), and to understand who may need special assistance during an evacuation (for example, elderly populations or individuals who cannot speak the primary language). Emergency managers must first understand the people whom they are trying to prepare before they can expect these people to take protective measures after receiving an official lahar warning or recognizing natural cues of a lahar (for example, ground shaking and rumbling noises).

To better understand societal vulnerability to Mount Rainier hazards, the Washington State Emergency Management Division (WEMD) sought assistance from the U.S. Geological Survey (USGS) to determine the number and type of people and assets that are in lahar-prone areas and how communities varied in their exposure to lahar hazards. Understanding how communities vary in their exposure to lahars helps emergency managers to understand potential lahar impacts and to determine where to supplement regional riskreduction strategies with site-specific efforts that are tailored to local conditions and needs (for example, targeted education programs and evacuation procedures).

\section{Purpose and Scope}

This report documents geographic variations in community exposure to lahar hazards associated with Mount Rainier, Washington. Community exposure is described by the amount and percentage of various assets in lahar-prone areas, based on the distribution of developed land, human populations, economic assets, and critical facilities relative to a Mount Rainier lahar-hazard zone. Variations in community exposure to lahars are based on the presence of assets in lahar-prone areas using geographic information system (GIS) tools; results are not engineering-based loss estimates for any particular facility. These inventories cannot be considered loss estimates because aspects of individual perceptions and preparedness levels before a lahar, adaptive capacity during a response, and long-term resilience after an event are excluded from this analysis (Alwang and others, 2001; Pelling, 2002; Turner and others, 2003). Reported inventories are loss estimates only if one assumes that all individuals in lahar-prone areas are unaware of lahar risks, are unaware of what to do if warned of an imminent threat (either by natural cues or official announcements), and fail to take protective measures to evacuate. This assumption is unrealistic, given the high number of hazard-awareness efforts in the Mount Rainier region (for example, Driedger and Scott, 2008; Driedger and others, 1998; Driedger and others, 2002; Driedger and others, 2005). Finally, this report focuses on inventorying assets in lahar-hazard zones of the various communities and does not 


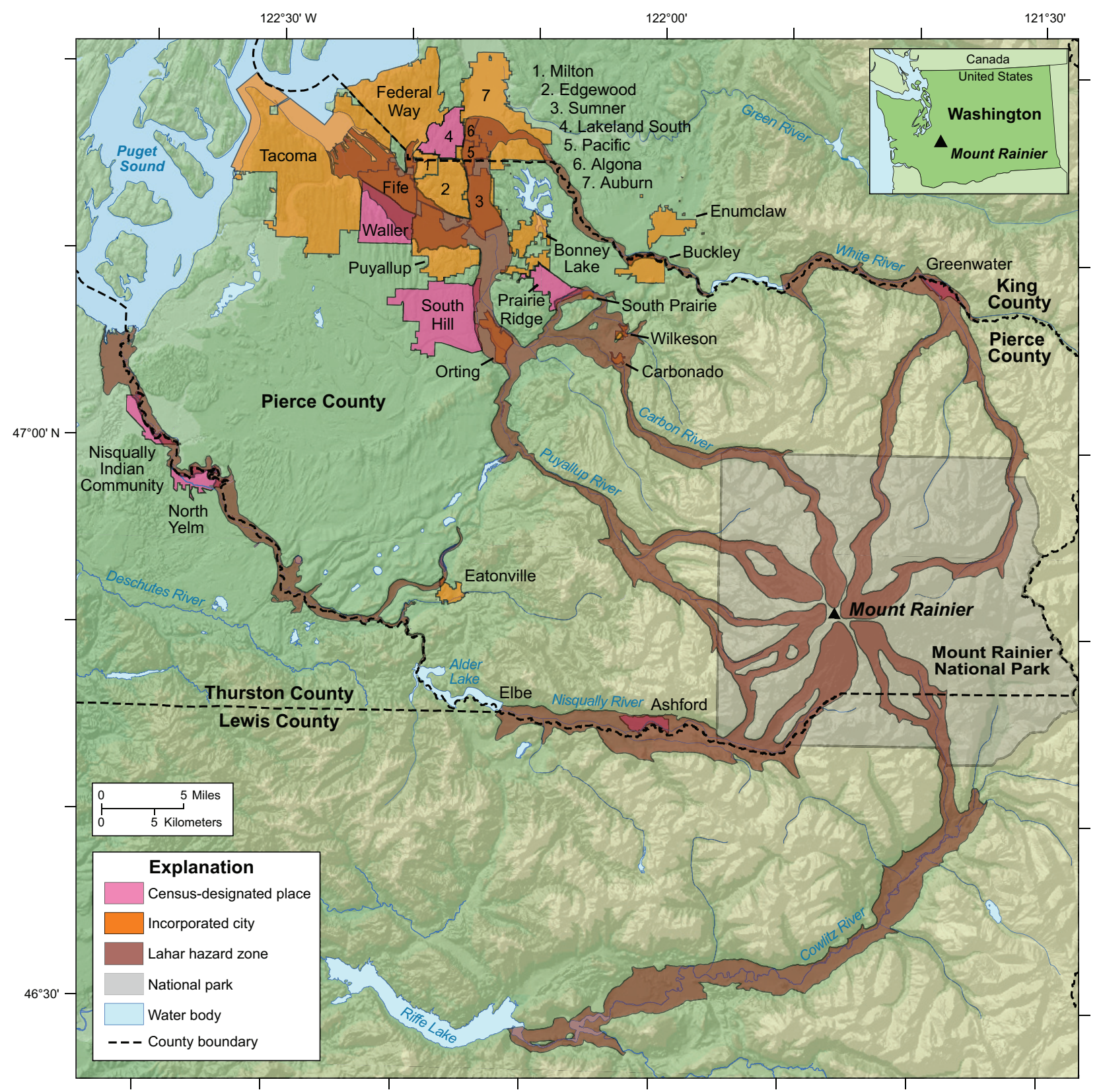

Figure 1. Map showing counties, incorporated cities, and census-designated places within a lahar-hazard zone on and near Mount Rainier, Washington (Hoblitt and others, 1998; Schilling and others, 2008).

include analysis of indirect losses to individuals, businesses, communities, or to the regional economy.

\section{Study Area}

This study of community exposure to lahar hazards focuses on the 18 cities and 9 unincorporated towns of four Washington counties (King, Lewis, Pierce, and Thurston) that include land within a Mount Rainier lahar-hazard zone (fig. 1). Incorporated cities and unincorporated towns are delineated by 2000 city limits and census-designated-place boundaries, respectively, of the U.S. Census Bureau (Office of Financial Management, 2009). The delineation of the Mount Rainier lahar-hazard zone used in this study is based on the behavior of the Electron Mudflow (noted as a "Case 1" scenario in Hoblitt and others, 1998, and Schilling and others, 2008). The Electron Mudflow traveled along the Puyallup River (fig. 1) approximately 500 years ago and was the result of a slope failure on the west flank of Mount Rainier. It was one of the largest lahars in the past several thousand years at Mount Rainier and is therefore considered to be a characteristic flow for identifying probable inundation areas from future lahars that could significantly affect downstream communities. 
Additional hazard zones for smaller, more likely, lahars that impact areas closest to the volcano have also been delineated (Hoblitt and others, 1998; Schilling and others, 2008). The Electron Mudflow, with no known evidence of an accompanying eruption (Sisson and Vallance, 2009), illustrates how some rare but significant lahar events can occur without precursory volcanic activity. Upstream reports of advancing lahars or signals from the lahar detection system may serve as the only warning for some downstream communities in the event of rare lahars that are not accompanied by volcanic unrest or activity (Driedger and Scott, 2008; Hoblitt and others, 1998).

The lahar-hazard zone shown in figure 1 identifies areas that could be affected by lahars generated in the various drainage valleys of Mount Rainier, based on the behavior of the Electron Mudflow. It is not meant to imply that all delineated areas would be inundated by a future lahar; typically a single lahar is confined to a single drainage valley (for example, Puyallup River). The west flank of Mount Rainier, including the Puyallup and Nisqually river valleys, is considered to have the greatest potential for generating large landslides that become significant lahars because of higher amounts of hydrothermally weakened rock at high altitudes (Driedger and Scott, 2008). Also, the areas in the identified lahar-hazard zone are not equally at risk from inundation; areas closer to the volcano and in stream bottoms are more likely to be affected than areas on the periphery of the zone or increasingly distant from the volcano. The lahar-hazard zone used in this study is a guide for emergency planning and is not a prediction for a future flow, because the actual inundation extent, depth, and speed of a future lahar will be determined by topography and the volume of material contained in the flow. Therefore, even if another Electron-sized lahar were to occur, some areas in the lahar-hazard zone will be covered by several meters of sediment from the high-speed debris flows while others will receive lahar-related flooding. Finally, the lahar-hazard zone used in this study does not include other hazards associated with volcanic activity of Mount Rainier, including lava flows, pyroclastic flows, ash fall, and flooding, nor does it include the subsequent sedimentation of areas further downstream of initial lahar deposits that follow lahar events for decades to centuries.

\section{Variations in Community Exposure}

We use the amount and percentage of six variables - developed land, residents, employees, public venues, dependent-population facilities, and parcel values - to describe the variation in community exposure to lahar hazards among the 27 communities and four counties. We chose these variables because they are all indicators of human occupation and land use in lahar-prone areas. They also are data that U.S. jurisdictions are encouraged to collect as they develop hazard mitigation plans (Federal Emergency Management Agency, 2001) to qualify for funds under the U.S. Hazard Mitigation Grant Program in accordance with the Disaster Mitigation Act of 2000, Public Law 106-390. Calculating the number and distribution of individuals and community assets in lahar-prone areas shows emergency managers where risk and warning education may be most needed and where, in the absence of evacuations, potential losses could be greatest. Calculating the percentage of community assets that are in a lahar-hazard zone provides insight about the relative impact of losses to an entire community.

Analyses were completed using geographic information system (GIS) software to overlay geospatial data representing population counts, landcover classification, administrative boundaries, and lahar-hazard zones. If GIS-based population polygons overlapped hazard polygons, final population values were adjusted proportionately using the spatial ratio of each sliver within or outside of the lahar-hazard zone. Several datasets have non-normal distributions, based on D'Agostino normality tests at 95 -percent significance (that is, $\alpha=0.05$ ) (Zar, 1984). Therefore, third-quartile (75th percentile) values are reported in each bar graph instead of standard deviations to highlight communities with higher exposure to lahar hazards. Communities with values higher than the third-quartile value are in the top 25 percent of the communities in a certain category and therefore have the highest relative exposure.

\section{Land Cover}

For each community, we calculated the amount and percentage of developed land within the lahar-hazard zone. We assumed that population and asset exposure increases as the area and percentage of developed land within lahar-prone areas increases (Wood, 2009). We used a subset of the 2001 National Land Cover Database (NLCD) (Homer and others, 2004) to identify land-use/land-cover (LULC) types in the study area (fig. 2). NLCD products are coded by automated techniques from 30-m spatial resolution Landsat Thematic Mapper (TM) digital satellite imagery and verified with field visits. The base scale of 1:100,000 for mapping applications and project accuracy standards of 85 percent make NLCD data (represented as $30-\mathrm{m}$ grid cells or pixels) appropriate for regional landscape pattern identification. To help assess variations in community exposure to lahar hazards, we focus on three NLCD classes of developed land:

- High-intensity developed pixels, which contain more than 80 percent impervious surfaces, contain little or no vegetation and typically represent heavily built-up urban centers, large buildings, and abundant paved surfaces, such as runways and interstate highways;

- Medium-intensity developed pixels, which contain 50 to 79 percent impervious surfaces, are a mix of constructed and vegetated surfaces, and typically represent single family housing units and associated outbuildings; and

- Low-intensity developed pixels, which contain 21 to 49 percent impervious surfaces and are similar to mediumintensity developed pixels with the addition of roads and associated trees (National Oceanic and Atmospheric Administration Coastal Services Center, 2007). 


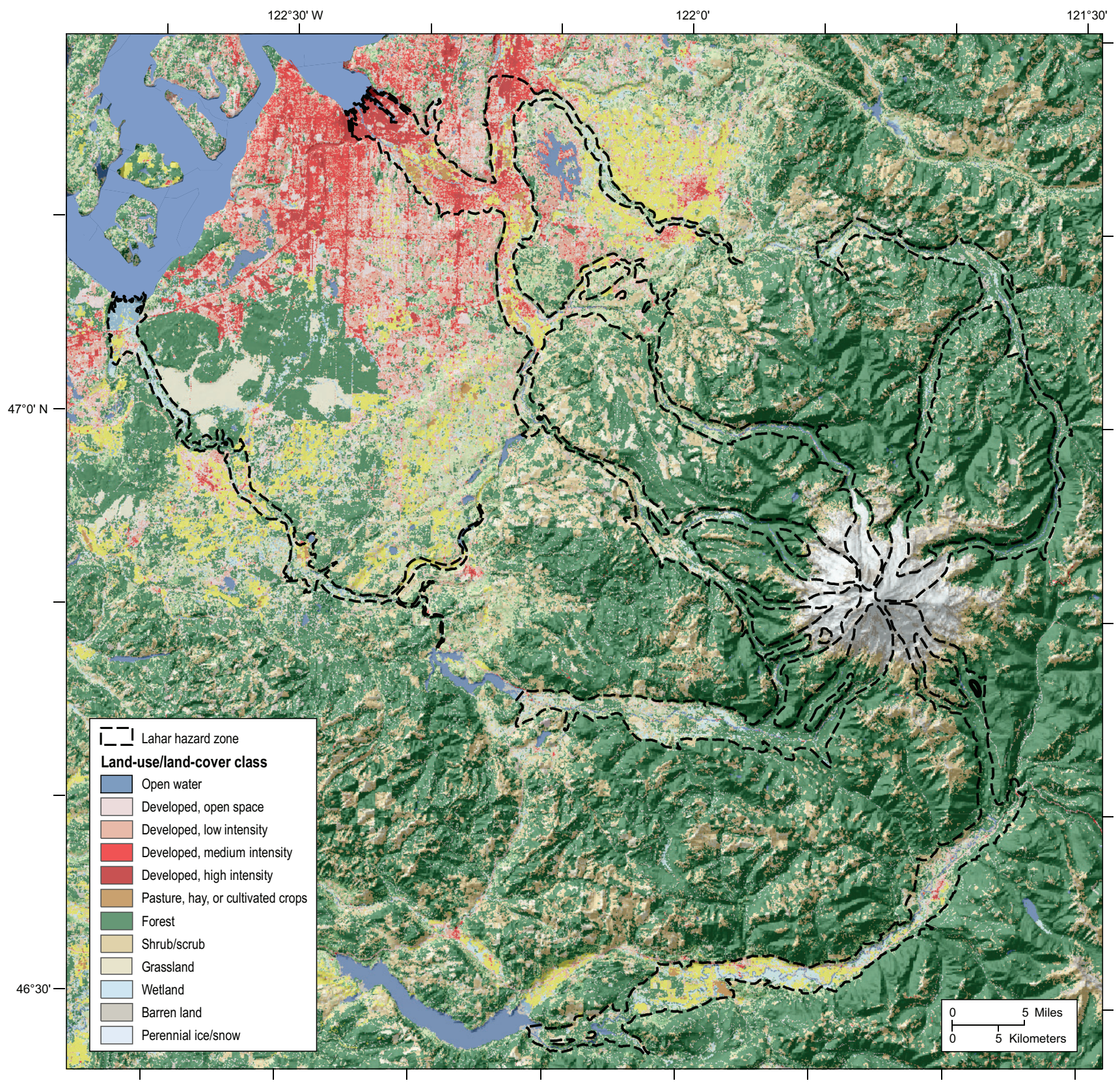

Figure 2. Map of a lahar-hazard zone associated with Mount Rainier, Washington (Hoblitt and others, 1998; Schilling and others, 2008), and land-cover data from the 2001 National Land Cover Database.

Based on a spatial overlay of 2001 NLCD data, administrative boundaries, and the lahar-hazard zone, the distribution of land-cover types (by area) in lahar-prone areas was determined for the entire study area (fig. 3). Percentages represent the amount of land area classified as a specific land-cover class (for example, grassland) relative to the total hazard-prone area. For the purposes of this report, all wetland-related NLCD classes are aggregated into one class, as are all forest-related classes. Ten percent of the LULC distribution in the Mount Rainier lahar-hazard zone is classified as developed, including low-intensity ( 5 percent), medium-intensity ( 3 percent), and high-intensity ( 2 percent) classes. The remaining lahar-prone land is classified as forest (44 percent), ice/snow ( 8 percent), wetlands ( 8 percent), pasture, hay, and cultivated crops ( 7 percent), shrub/scrub ( 7 percent), open-space developed (5 percent), barren land (4 percent), grassland ( 3 percent), and open water ( 3 percent). The entire four-county study area has similar LULC percentages (that is, plus or minus 2 percent), except for less snow/ice (1 percent compared to 8 percent in the hazard zone), less wetlands ( 3 percent compared to 8 percent in the hazard zone), and more forest (59 percent compared to 44 percent in the hazard zone). Land classified as undeveloped (for example, forest, shrub/scrub, open-space, grassland, wetlands) may still represent vulnerability issues 


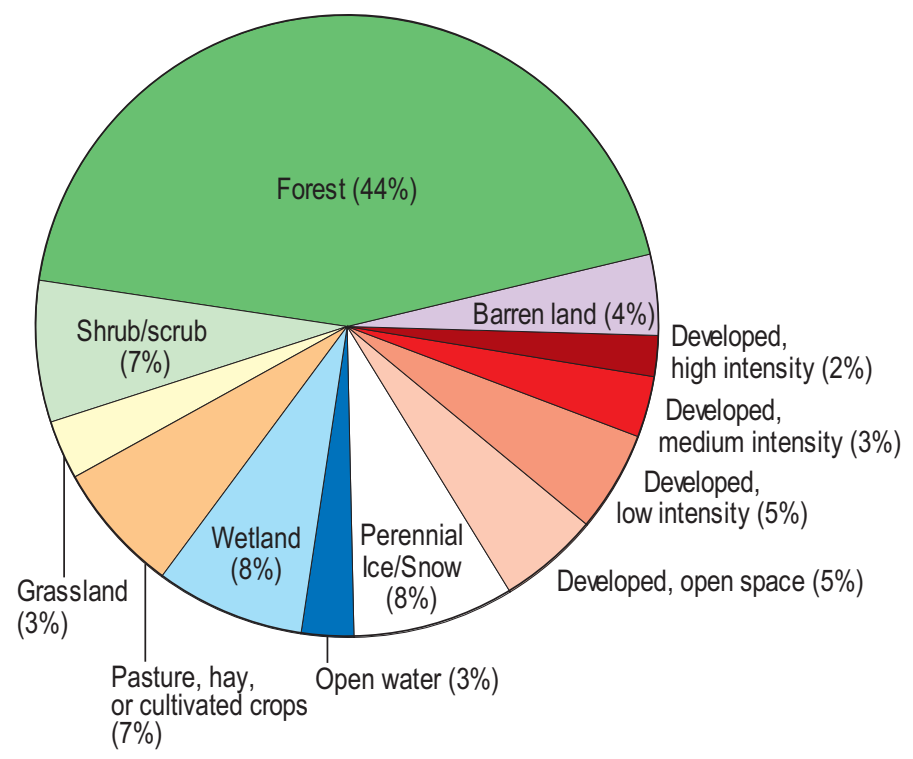

Figure 3. Distribution of land-cover classes (by area) in the selected Mount Rainier lahar-hazard zone.

in the four counties, because these areas can attract significant numbers of recreationists (for example, hikers in Mount Rainier National Park or paddlers on waterways).

The amount (fig. $4 A$ ) and percentage (fig. $4 B$ ) of developed land (NLCD cells classified as low-, medium-, or highintensity developed) in lahar-prone areas varies within the 27 communities and four counties. In the y-axes of figure 4, as well as in subsequent bar graphs in this report, communities are arranged alphabetically first by county (King, Lewis, Pierce, and Thurston) and then by community within each county. Third-quartile values (75th percentile) are noted to highlight communities with the highest relative exposure. The unincorporated areas of Pierce County (4,029 acres), as well as the City of Tacoma (3,717 acres) and the City of Puyallup (2,940 acres), contain the three largest areas of developed land in the lahar-hazard zone, but these lands represent low to moderate percentages of the total developed land in each jurisdiction (5 percent, 14 percent, and 54 percent, respectively). Several communities (for example, Ashford, Carbonado, Fife, Greenwater, Orting, and Wilkeson) have relatively low amounts of developed land in the lahar-hazard zone, but these lands make up all of the developed land for each community. Only a few communities (for example, Pacific, Fife, and Sumner) are above the third-quartile values for both amount and percentage of land in the lahar-hazard zone.

The majority of developed land in the lahar-hazard zone is classified as medium- and low-intensity developed, which likely represents single-family housing and associated buildings (for example, garages, sheds). Some communities, such as Tacoma, have large amounts of high-intensity developed land that likely represent heavily built-up urban areas (for example, Port of Tacoma, highways). The large amounts of low-intensity developed land in the unincorporated portions of
Pierce and Lewis counties likely represent single-family housing in more rural environments.

\section{Residential Populations}

The number and type of residents in the lahar-hazard zone were assessed by overlaying and calculating the union of lahar-hazard zone, community boundaries, and block-level population counts compiled for the 2000 U.S. Census (U.S. Census Bureau, 2008). The lahar-hazard zone contains approximately 78,049 residents and 30,713 households (table 1), both representing approximately 3 percent of the total amounts in the four counties. The number (fig. $5 A$ ) and percentage (fig. $5 B$ ) of residents in the lahar-hazard zone vary significantly across the four counties. The City of Puyallup has the highest number of residents in the lahar-hazard zone $(17,459$ residents), and several communities (for example, Fife and Orting) have 100 percent of their residents in the lahar-hazard zone. As with the LULC data, there are several areas with high numbers but relatively low percentages of total residents in the lahar-hazard zone (for example, City of Auburn and the unincorporated areas of Pierce County), while other areas have low numbers and high percentages of residents in lahar-prone areas (for example, Algona, Pacific, Ashford, Carbonado, Elbe, and Wilkeson). Only the cities of Fife, Orting, and Sumner have both high numbers and high percentages of their residents in the lahar-hazard zone (denoted by these cities having values above the third quartile in both categories). Twenty-one percent of the residents in lahar-prone areas live outside of the incorporated cities and unincorporated communities within the four counties, indicating the importance of awareness programs and evacuation planning for rural residents.

Demographic factors, such as age, ethnicity and tenancy, can amplify an individual's sensitivity to hazards (Morrow, 1999; Ngo, 2003; Cutter and others, 2003; Laska and Morrow, 2007). Therefore, in addition to general population counts, we calculated the number of residents in lahar-prone areas according to ethnicity (Hispanic or Latino), race (American Indian and Alaska Native, Asian, Black or African American, Native Hawaiian and other Pacific Islander, and White either all alone for each race or in combination with one or more other races), age (individuals under 5 and over 65 years in age), gender (female-headed households with children and no spouse present), and tenancy (renter-occupied households). Categories to discuss demographic sensitivities are not based on extensive studies of residents in the Mount Rainier laharhazard zone, but instead on past social-science research of all types of disasters (for example, earthquakes, hurricanes). It is not implied that all individuals of a certain group will exhibit identical behavior. The extent of these demographic sensitivities will be influenced by variations in local physical and social context, level of preparedness prior to a lahar, and ability to respond during an event.

Race and ethnicity have been shown to influence individual sensitivity to natural hazards because of historic patterns of social inequalities within the United States that can result 


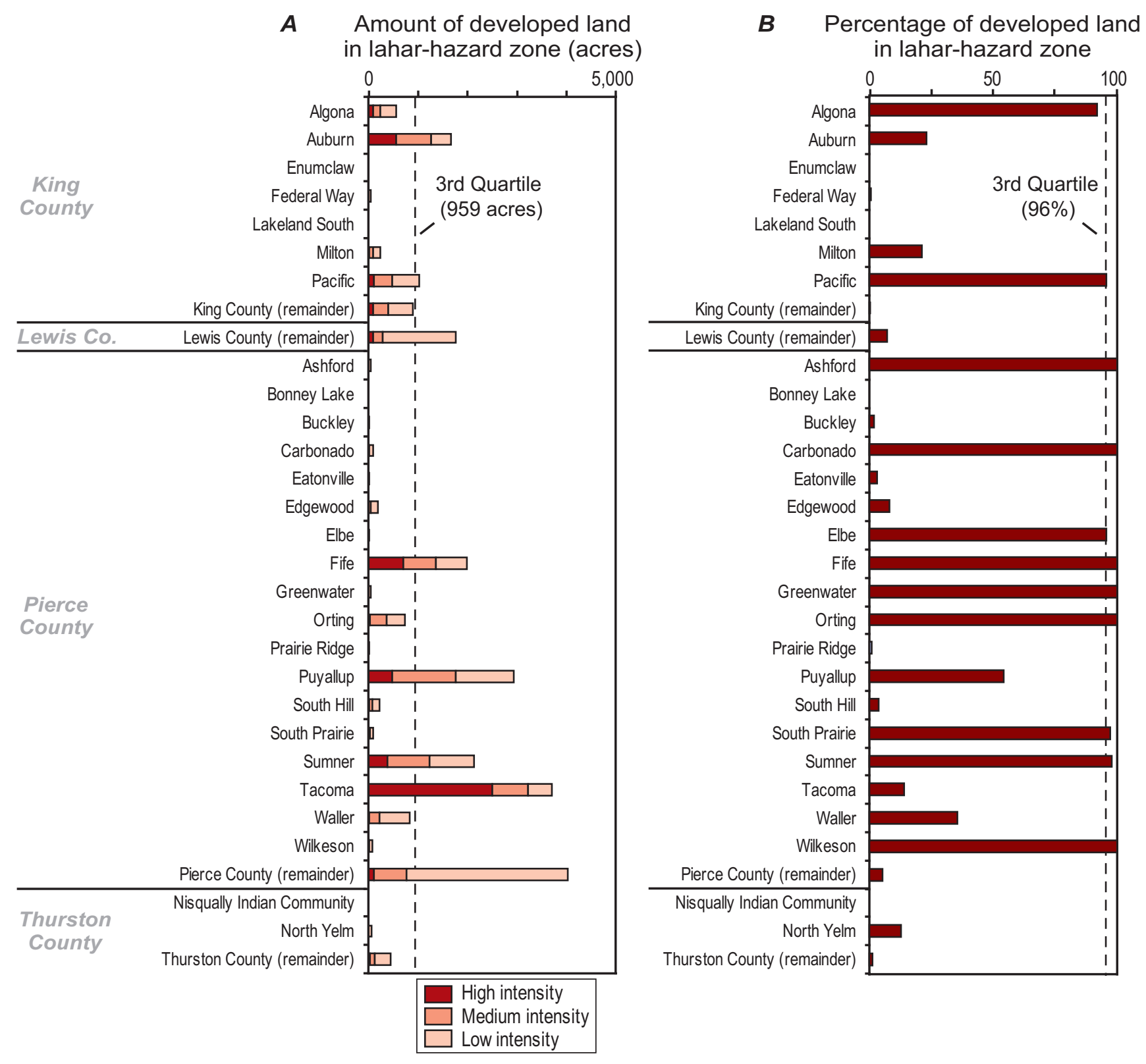

Figure 4. Amount $(A)$ and percentage $(B)$ of developed land in the selected lahar-hazard zone for communities downstream of Mount Rainier. Third-quartile (75th percentile) values are reported to highlight the top 25 percent of communities with the relatively highest values in the data.

in minority communities lacking resources to prepare and mitigate (Cutter and others, 2003; Laska and Morrow, 2007) and being excluded from disaster planning efforts (Morrow, 1999). Relative to national percentages of race and ethnicity, the percentage of residents in the lahar-hazard zone is high for White (90 percent compared to 77 percent for the nation) and American Indian and Alaska Native (4 percent compared to 2 percent for the nation), low for Black or African American (2 percent compared to 13 percent for the nation), and equal for Asian (4 percent) and Native Hawaiian and Other Pacific Islander (both less than 1 percent). Comparisons of race and ethnicity of residents in lahar-prone areas to those of the entire study-area population indicate that no group is disproportionately represented in lahar-prone areas, aside from slightly higher percentages of individuals that identify themselves as White (90 percent for the lahar-hazard zone and 81 percent for the four-county area). Within the 27 communities, the maximum percentage of residents in the lahar-hazard zone reporting a non-White race (alone or in combination with one or more other races) is low for most race categories, including Black or African American (9 percent), Asian (8 percent), and Native Hawaiian and Other Pacific Islander (4 percent). The one exception is the high percentage of residents that identify themselves as American Indian and Alaska Native (76 percent) within the Nisqually Indian Community (fig. 1). 
Table 1. Block-level demographic characteristics for residential populations in the selected lahar-hazard zone of Mount Rainier, Washington, based on the 2000 U.S. Census.

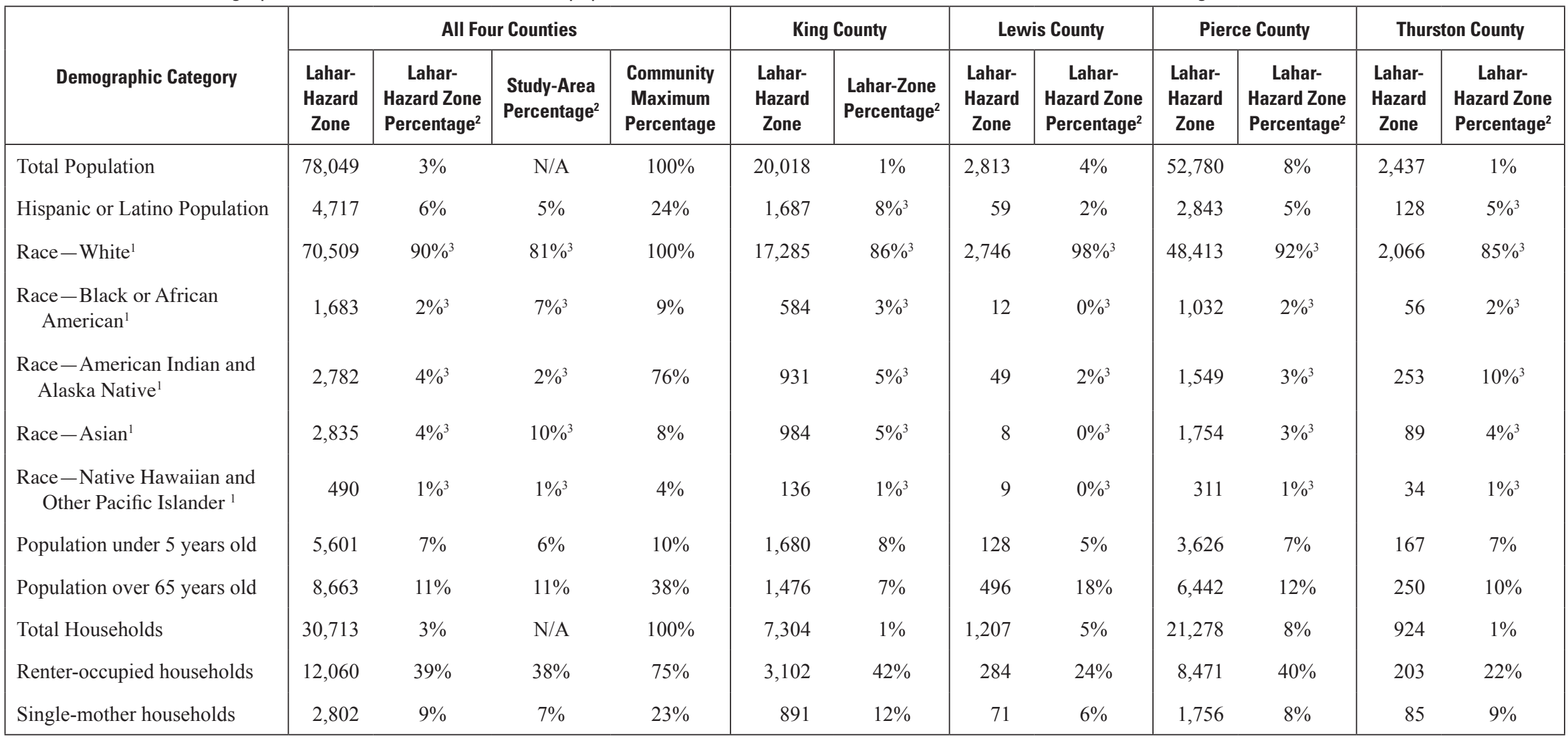

${ }^{1}$ Alone or in combination with one or more other races.

${ }^{2}$ Lahar-hazard-zone percentages refer to the percentage of individuals (or households for the last three rows) in the lahar-hazard zone of a specific demographic category. Study area percentages refer to the percentage of individuals (or households) in the four counties (King, Lewis, Pierce, and Thurston) of a specific demographic category.

${ }^{3}$ The sum of percentages by race will not sum to $100 \%$, as individuals are able to report multiple race categories in Census Bureau reports. 

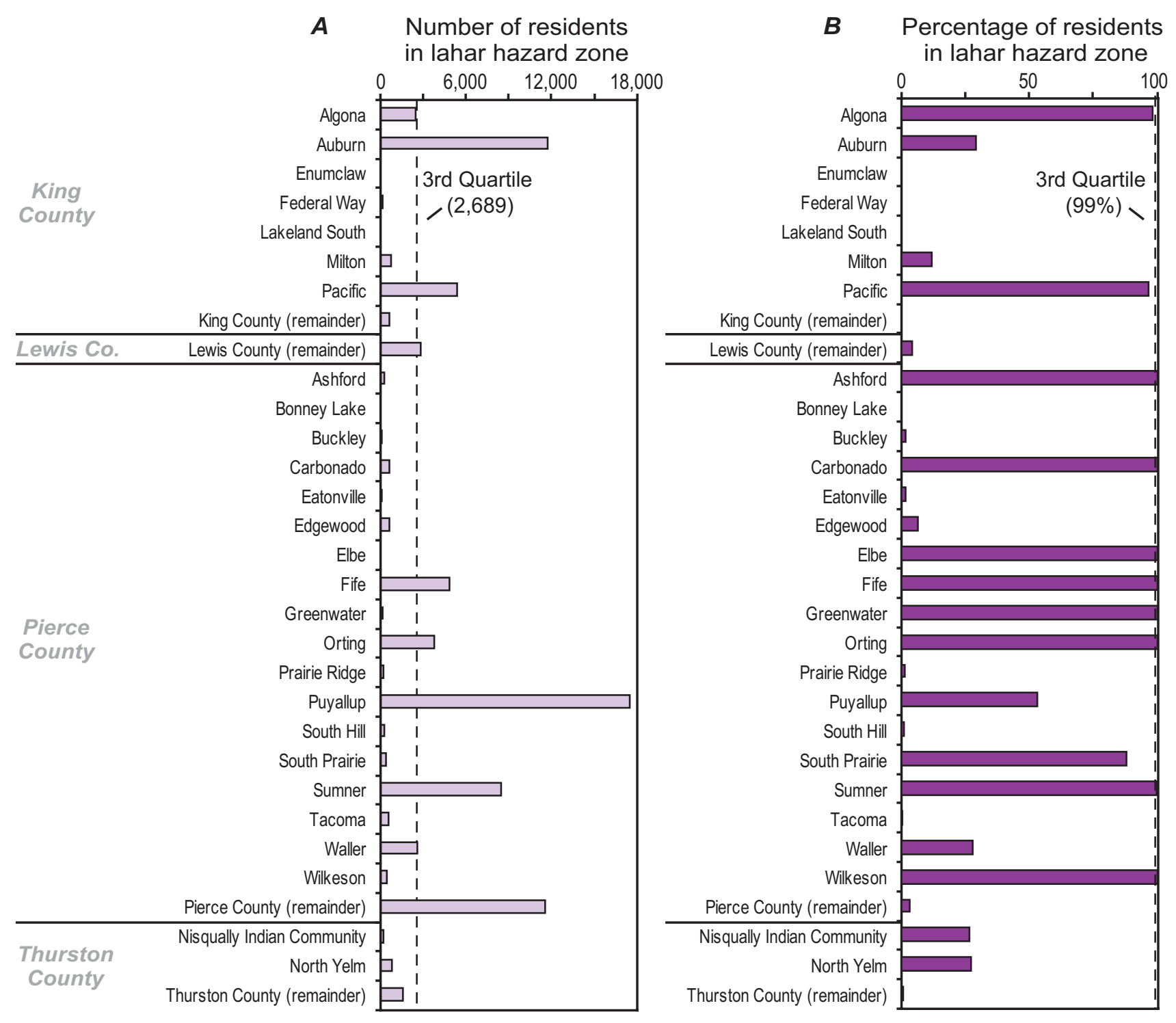

Figure 5. Number $(A)$ and percentage $(B)$ of residents in the selected lahar-hazard zone for communities downstream of Mount Rainier.

Seven percent of residents in the lahar-hazard zone are under the age of 5 , and 11 percent are older than 65 years in age - two groups considered to be more vulnerable to suddenonset hazards than other age groups because of potential mobility and health issues (Morrow, 1999; Balaban, 2006; McGuire and others, 2007; Ngo, 2003). Individuals less than 5 years in age represent from 0 percent to 10 percent (Orting) of residents in the lahar-hazard zone, whereas individuals older than 65 years represent from 0 to 38 percent (Elbe) of those in the hazard zone. Targeted education and lahar-evacuation training may be needed in communities with higher numbers of very young and older populations.

Two household attributes that demonstrate high variability in the study area are renter-occupied households (fig. $6 A$ ) and single-mother households (fig. $6 B$ ). Thirty-nine percent of the households in the lahar-hazard zone are renter-occupied (table 1), a demographic group that is typically less likely to be prepared for catastrophic events and may have less exposure to risk-awareness campaigns than homeowners (Morrow, 1999; Burby and others, 2003). The percentage of renteroccupied households in the lahar-hazard zone ranges from 0 percent to 75 percent (City of Fife) (fig. 6A). Nine percent of households in the lahar-hazard zone are single-mother households, which are more likely to have limited mobility during an evacuation from a sudden-onset hazard and fewer financial resources to draw upon to prepare for natural hazards and to recover from a disaster (Enarson and Morrow, 1998; Laska and Morrow, 2007). The highest percentage of single-mother households in the lahar-hazard zone ( 23 percent) is in the Nisqually Indian Community (fig. $6 B$ ). 


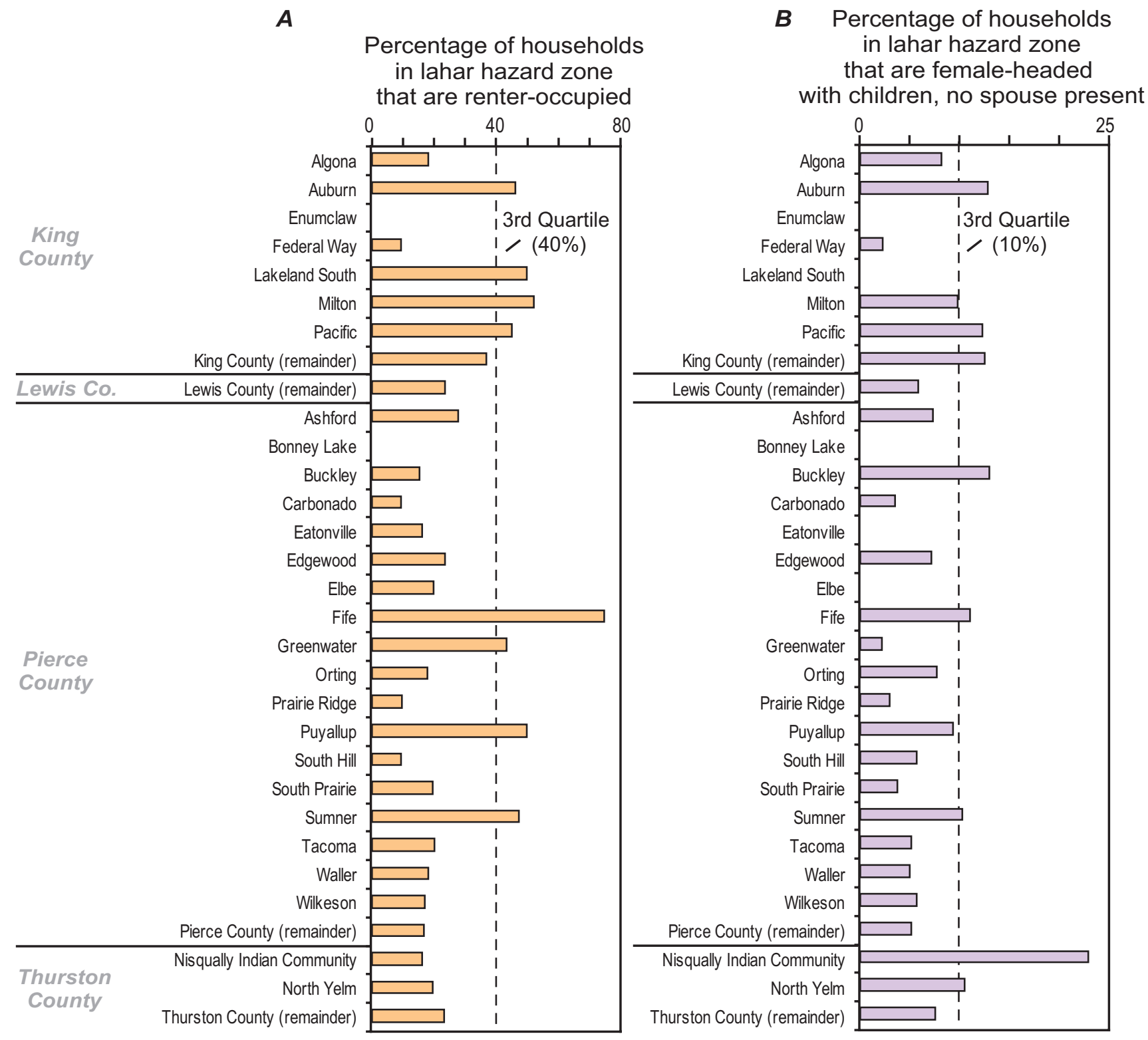

Figure 6. Percentages of households in the selected Mount Rainier lahar-hazard zone that are $(A)$ renter-occupied households and $(B)$ female-headed households with children and no spouse present.

Differences between 1990 and 2000 U.S. Census population counts in the number (fig. $7 A$ ) and percentage (fig. $7 B$ ) of residents in lahar-prone areas of the 27 communities and four counties were calculated to better understand how communities have occupied lahar-prone areas over time. Although laharprone areas in this study area have seen an increase of 11,233 residents between 1990 and 2000 (primarily in Auburn, Orting, Puyallup, and the unincorporated areas of Pierce County), the percentage of residents in lahar-prone areas in these communities has not increased significantly (plus or minus 1 percent in most cases). In some cases (for example, Orting), this is because a community is already entirely in the lahar-hazard zone and growth in non-hazard areas is not possible (unless they decide to annex adjacent, non-hazard land into city limits). The largest increase in the number of residents between 1990 and 2000 was in the City of Puyallup ( $+2,232$ residents); however, the percentage of residents in the lahar-hazard zone decreased from 59 to 53 percent. This indicates that the City of Puyallup has grown but has done so less in lahar-prone areas of its community. Other communities that experienced a decrease in the percentage of residents in the lahar-hazard zone include South Prairie and the Nisqually Indian Community. The greatest percentage increase for residents in the lahar-hazard zone is in the unincorporated community of North Yelm, which experienced a 9-percent increase (from 18 to 27 percent) of total residents between 1990 and 2000 . 


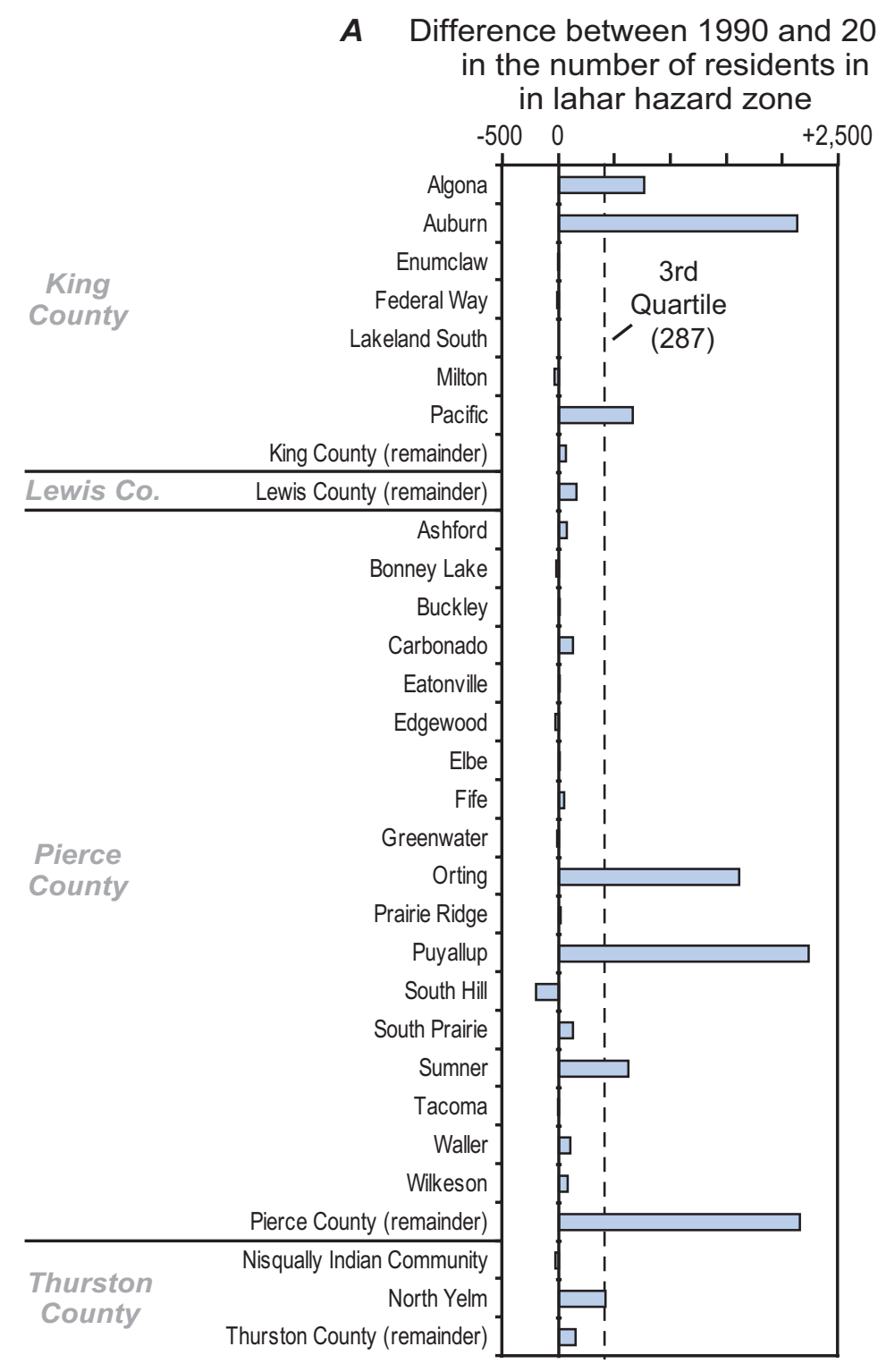

B Difference between 1990 and 2000 in the percentage of residents in lahar hazard zone

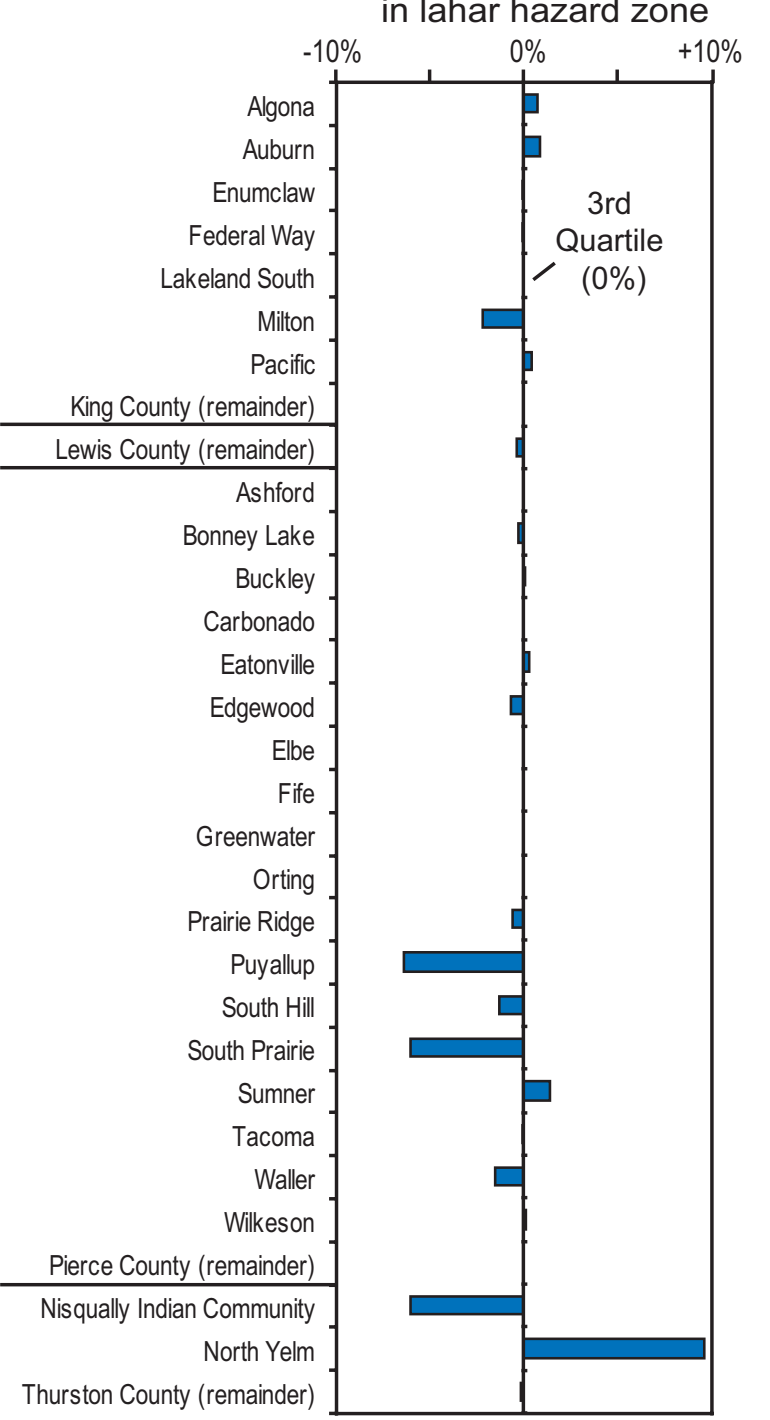

Figure 7. Difference between 1990 and 2000 in the number $(A)$ and percentage $(B)$ of residents in the selected Mount Rainier laharhazard zone.

Comparisons between 2000 population counts and 2007 population estimates (U.S. Census Bureau, 2008) for several communities in the study area suggest that the number of residents in the lahar-hazard zone continues to increase. Calculations are not possible for all 27 communities because geospatial data (for example, census blocks) are not currently available for 2007 population estimates. Instead, we limit our discussion to the communities that are entirely in the lahar-hazard zone, including Ashford, Carbonado, Elbe, Fife, Greenwater, and Orting. Because these communities are entirely within the lahar-hazard zone, we assume any changes in community population can be considered changes in the in-hazard population. Population estimates for the small communities of Ashford, Elbe, and Greenwater are not available, therefore we comment only on Carbonado, Fife, and Orting. Between 2000 and 2007, community population is estimated to have decreased in Carbonado ( -15 residents), but increased in Fife $(+3,026$ residents $)$ and Orting $(+2,183$ residents). The estimated increase in population between 2000 and 2007 for Fife and Orting is 5,209 residents, representing population increases in each town by 63 and 59 percent, respectively, and an overall 7 percent increase in the in-hazard population for the region. Further comparative studies on increasing population exposure to Mount Rainier lahars will be possible as future U.S. population counts are completed. 


\section{Employees}

The number and types of employees in lahar-prone areas are based on an overlay of the lahar-hazard zone and the 2008 InfoUSA Employer Database (InfoUSA, 2008). Our counts serve as approximations because we were unable to fieldverify the locations of the 108,182 businesses within the four counties of the study area. To identify types of employees and primary business sectors that are in lahar-prone areas, we used North American Industry Classification System (NAICS) codes (see appendix A of Wood, 2007, for codes) to define the distribution of employees by business sector, an indicator routinely used to evaluate economic health and market trends (Bureau of Labor Statistics, 2007).

The lahar-hazard zone contains 59,678 employees at 3,890 businesses, both representing 4 percent of the businesses and the employees in the four counties (table 2). The percentage of the total workforce in the lahar-hazard zone of each county ranges from less than 1 percent in Thurston County to 18 percent in Pierce County. The 3,890 businesses in the lahar-hazard zone generated approximately $\$ 16$ billion in sales in 2008 ( 7 percent of the study-area total). The majority of this sales volume (\$15 billion) came from businesses in Pierce County, which also represented 31 percent of total generated sales within Pierce County. As with residential populations, the number (fig. 8A) and percentage (fig. 8B) of employees in lahar-hazard zones vary considerably in the study area. The City of Puyallup has the highest number of employees working within the lahar-hazard zone $(12,603)$, and all of the employees of several communities (for example, Fife, Orting) work within the lahar-hazard zone. Some communities have high numbers but low percentages of employees in the laharhazard zone (for example, Tacoma), while others have fewer employees that represent an entire town's workforce in these areas (for example, Pacific, Orting). The cities of Fife and Sumner have both relatively high numbers and high percentages of their employees in the lahar-hazard zone.

On the basis of employee distributions, the primary business sectors in the lahar-hazard zone are in manufacturing, retail trade, transportation and warehousing, wholesale trade, and construction (fig. 9). Retail businesses attract local customers and tourists and therefore could contain significant numbers of people with little awareness of lahar hazards or of how to evacuate. Education efforts for employees at retail businesses ideally would include discussions about how employees will help customers evacuate, because employees will need to assume the on-site role of emergency manager for tourists likely unaware of lahar risks. Employees in the laharhazard zone may be unaware of lahar hazards or proper evacuation strategies, especially if they do not live in lahar-prone areas themselves, are not well connected to the community, and are reliant on business owners for information.

Nonretail businesses (for example, manufacturing and warehousing) tend to involve high numbers of employees, low numbers of tourists, heavy machinery, and possibly hazardous material. In addition, the success of these predominantly industrial sectors depends on their ability to transport raw materials and finished products via functioning transportation infrastructure, such as the Port of Tacoma, interstate and state roads, and railroads (additional discussion on this topic can be found in the section on "Critical and Essential Facilities and Infrastructure"). Risk awareness and education efforts for employees at industrial businesses (fig. 3) ideally would address the potential for hazardous materials or infrastructure (for example, power lines and cranes) to obstruct or constrain an individual's ability to evacuate before an imminent lahar

\section{Dependent Populations and Public Venues}

To provide some insight into nonresidential populations, we used NAICS codes in the 2008 InfoUSA Employer Database to identify dependent-population facilities and public venues in the study area. The high volume of facilities and dynamic nature of populations at these venues and facilities precluded our ability to determine exact population counts; therefore, discussions of these locations are limited to the number of venues and facilities. Dependent-population facilities contain individuals who would require assistance to evacuate and include hospitals, psychiatric and substance abuse hospitals, adult residential care and nursing homes,

Table 2. Amount and percentage of economic assets in the selected lahar-hazard zone of Mount Rainier, Washington.

\begin{tabular}{|c|c|c|c|c|c|c|c|c|c|c|}
\hline & \multicolumn{2}{|c|}{ All Four Counties } & \multicolumn{2}{|c|}{ King County } & \multicolumn{2}{|c|}{ Lewis County } & \multicolumn{2}{|c|}{ Pierce County } & \multicolumn{2}{|c|}{ Thurston County } \\
\hline & $\begin{array}{l}\text { Lahar- } \\
\text { Hazard } \\
\text { Zone }\end{array}$ & $\begin{array}{c}\text { Percentage } \\
\text { of Four- } \\
\text { County Total }\end{array}$ & $\begin{array}{c}\text { Lahar- } \\
\text { Hazard } \\
\text { Zone }\end{array}$ & $\begin{array}{c}\text { Percentage } \\
\text { of County } \\
\text { Total }\end{array}$ & $\begin{array}{l}\text { Lahar- } \\
\text { Hazard } \\
\text { Zone }\end{array}$ & \begin{tabular}{|c|} 
Percent- \\
age of \\
County \\
Total \\
\end{tabular} & $\begin{array}{l}\text { Lahar- } \\
\text { Hazard } \\
\text { Zone }\end{array}$ & $\begin{array}{c}\text { Percentage } \\
\text { of County } \\
\text { Total }\end{array}$ & $\begin{array}{l}\text { Lahar- } \\
\text { Hazard } \\
\text { Zone }\end{array}$ & $\begin{array}{c}\text { Percentage } \\
\text { of County } \\
\text { Total }\end{array}$ \\
\hline Businesses & 3,890 & $4 \%$ & 376 & $1 \%$ & 103 & $4 \%$ & 3,374 & $15 \%$ & 37 & $0 \%$ \\
\hline Business employees & 59,678 & $4 \%$ & 4,603 & $0 \%$ & 512 & $2 \%$ & 54,248 & $18 \%$ & 315 & $0 \%$ \\
\hline Sales volume ( $\$$, billions) & $\$ 16.2$ & $7 \%$ & $\$ 1.2$ & $1 \%$ & $\$ 0.7$ & $1 \%$ & $\$ 14.9$ & $31 \%$ & $\$ 0.7$ & $1 \%$ \\
\hline Tax parcel value ( $\$$, billions) & $\$ 8.8$ & $2 \%$ & $\$ 1.8$ & $1 \%$ & $\$ 0.4$ & $5 \%$ & $\$ 6.5$ & $11 \%$ & $\$ 0.2$ & $0 \%$ \\
\hline
\end{tabular}




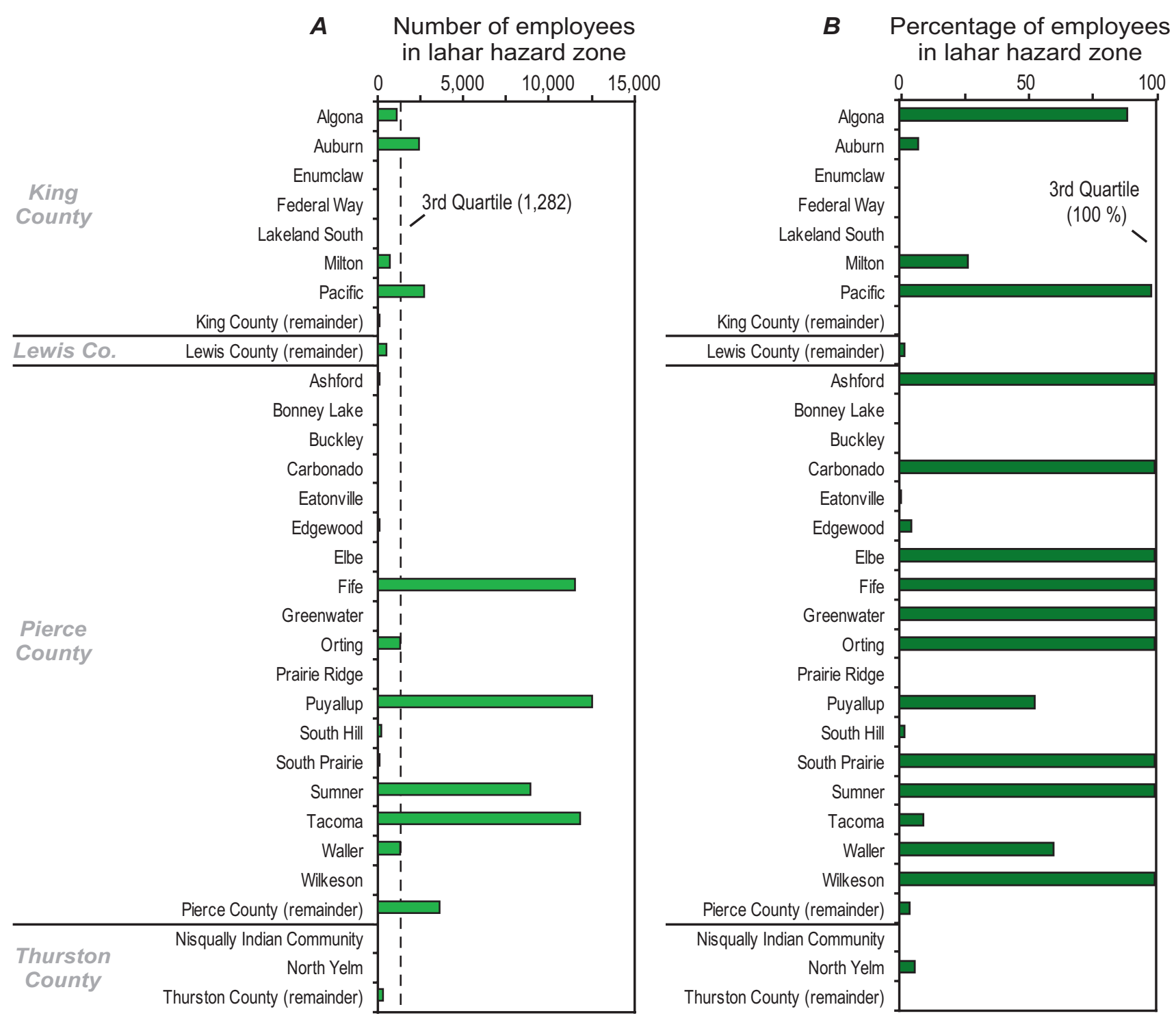

Figure 8. Number $(A)$ and percentage $(B)$ of employees in the selected lahar-hazard zone for communities downstream of Mount Rainier.

child day-care centers, schools, and correctional facilities. Several dependent-population facilities are in the laharhazard zone, including 63 schools and educational facilities, 30 child day-care centers, 19 adult residential care centers, 4 outpatient-care facilities, and 1 correctional facility (table 3; fig. 10). The highest number of dependent-population facilities in the lahar-hazard zone is in the City of Puyallup, and they include schools, adult residential care centers, and child daycare centers. Additional evacuation planning may be required in communities with high numbers of dependent-population facilities (for example, Puyallup, Sumner, Auburn) because of the limited mobility of certain groups at these facilities, such as those in schools and nursing homes. In addition to unique evacuation and relief issues, many dependent-population facilities represent critical social services that, if lost, could slow community recovery following an extreme event. For example, the loss of day-care centers could keep parents at home, thereby slowing business recovery.

Public venues attract both residents and tourists and include aquariums, botanical gardens, casinos, colleges and universities, historical places, libraries, museums, overnight accommodations, parks, religious organizations, shopping centers and malls, sporting facilities, theaters (including live and cinematic), and zoos. Many public venues that likely attract high numbers of residents and tourists are in the lahar-hazard zone, including 78 religious organizations, 57 overnight-tourist accommodations, 7 libraries, 7 fairgrounds, parks or zoos, 6 museums, 1 college or university, and 1 casino (table 4; fig. 11). The highest numbers of public venues in the lahar-hazard zone are in Puyallup, Fife, and the unincorporated areas of 


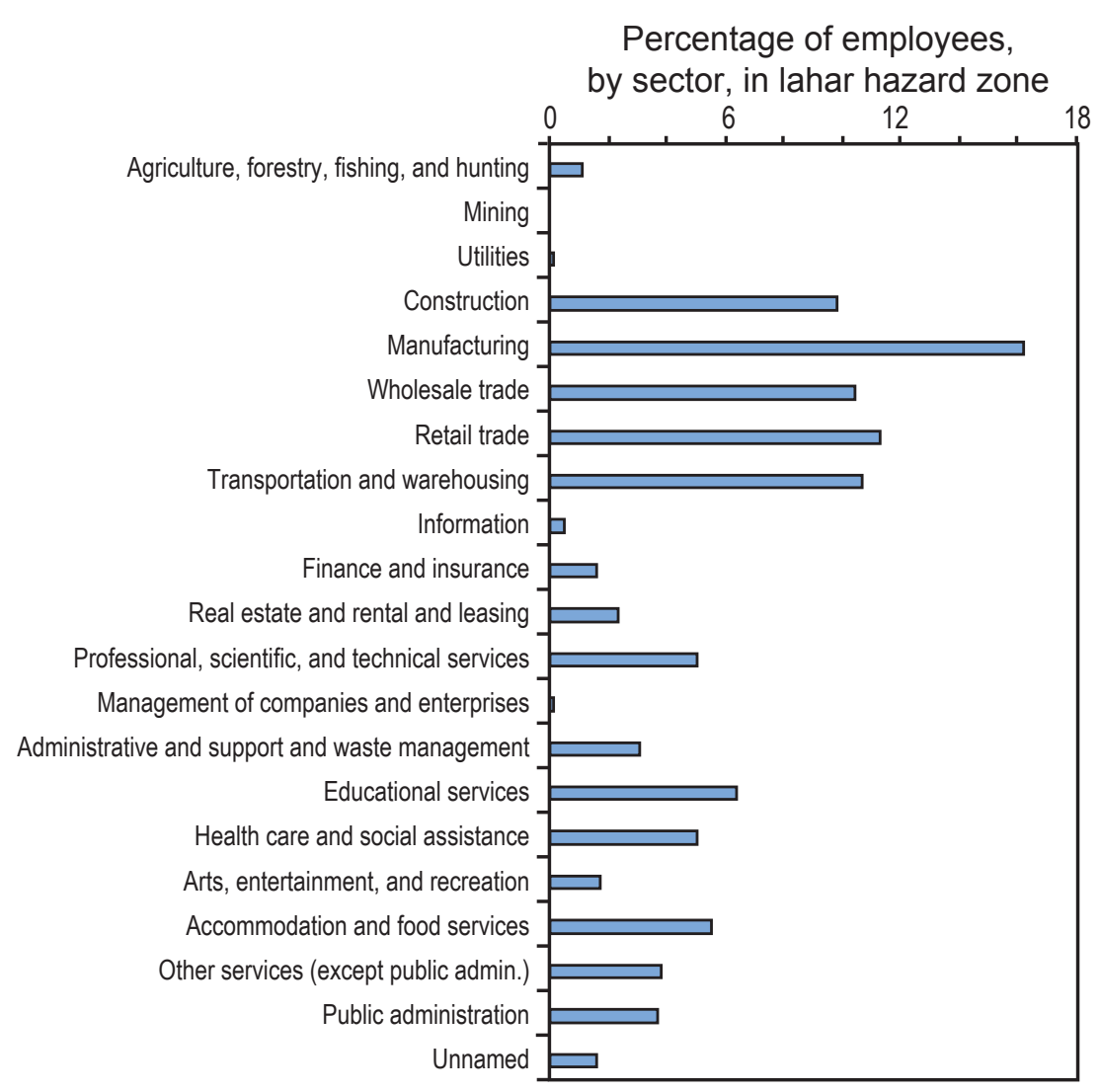

Figure 9. Percentage of employees, by business sector, in the selected Mount Rainier lahar-hazard zone.

Table 3. Amount and percentage of dependent-population facilities in the selected lahar-hazard zone of Mount Rainier, Washington.

\begin{tabular}{|c|c|c|c|c|c|c|c|c|c|c|}
\hline & \multicolumn{2}{|c|}{ All Four Counties } & \multicolumn{2}{|c|}{ King County } & \multicolumn{2}{|c|}{ Lewis County } & \multicolumn{2}{|c|}{ Pierce County } & \multicolumn{2}{|c|}{ Thurston County } \\
\hline & $\begin{array}{c}\text { Lahar- } \\
\text { Hazard } \\
\text { Zone }\end{array}$ & $\begin{array}{c}\text { Percentage } \\
\text { of Four- } \\
\text { County Total }\end{array}$ & $\begin{array}{l}\text { Lahar- } \\
\text { Hazard } \\
\text { Zone }\end{array}$ & \begin{tabular}{|c|}
$\begin{array}{c}\text { Percentage } \\
\text { of County } \\
\text { Total }\end{array}$ \\
\end{tabular} & $\begin{array}{l}\text { Lahar- } \\
\text { Hazard } \\
\text { Zone }\end{array}$ & $\begin{array}{c}\text { Percentage } \\
\text { of County } \\
\text { Total } \\
\end{array}$ & $\begin{array}{l}\text { Lahar- } \\
\text { Hazard } \\
\text { Zone }\end{array}$ & \begin{tabular}{|c|} 
Percentage \\
of County \\
Total \\
\end{tabular} & $\begin{array}{c}\text { Lahar- } \\
\text { Hazard } \\
\text { Zone } \\
\end{array}$ & $\begin{array}{c}\text { Percentage } \\
\text { of County } \\
\text { Total } \\
\end{array}$ \\
\hline $\begin{array}{l}\text { Adult-residential-care } \\
\text { facilities }\end{array}$ & 19 & $3 \%$ & 2 & $1 \%$ & 1 & $4 \%$ & 16 & $12 \%$ & 0 & $0 \%$ \\
\hline Child-day-care facilities & 30 & $3 \%$ & 9 & $2 \%$ & 0 & $0 \%$ & 21 & $8 \%$ & 0 & $0 \%$ \\
\hline Hospitals & 0 & $0 \%$ & 0 & $0 \%$ & 0 & $0 \%$ & 0 & $0 \%$ & 0 & $0 \%$ \\
\hline Outpatient-care facilities & 4 & $1 \%$ & 0 & $0 \%$ & 1 & $20 \%$ & 3 & $5 \%$ & 0 & $0 \%$ \\
\hline $\begin{array}{l}\text { Psychiatric and substance } \\
\text { abuse hospitals }\end{array}$ & 2 & $2 \%$ & 1 & $2 \%$ & 0 & $0 \%$ & 1 & $4 \%$ & 0 & $0 \%$ \\
\hline
\end{tabular}




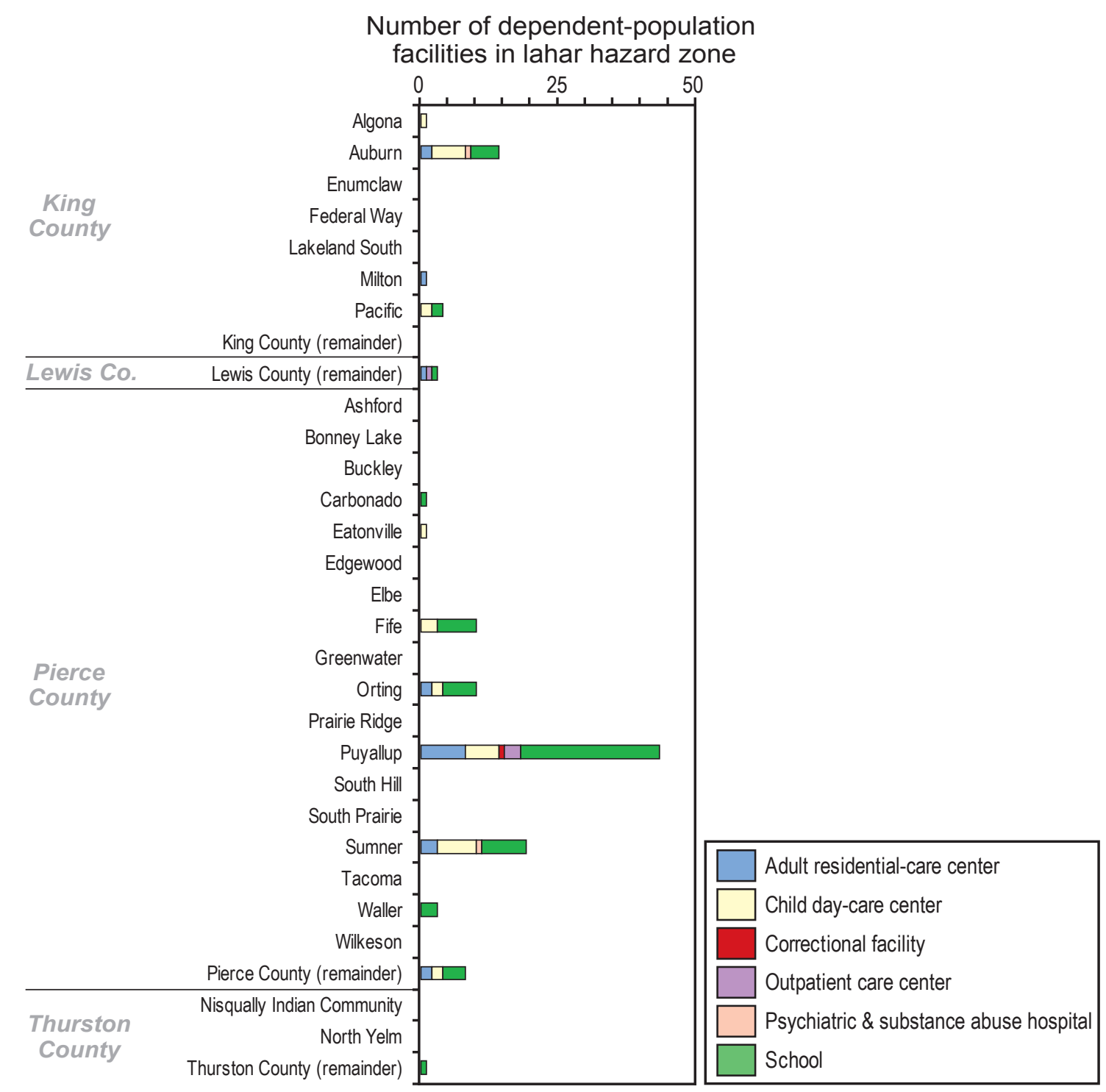

Figure 10. Number of dependent-population facilities in the selected lahar-hazard zone for communities downstream of Mount Rainier.

Lewis and Pierce Counties. The majority of public venues in the lahar-hazard zone are religious organizations (for example, churches) in Puyallup and overnight-tourist accommodations in Fife and the unincorporated portions of Lewis and Pierce Counties. Large numbers of visitors could be in danger if a lahar were to occur during a high-occupancy time (for example, during a religious service or community fair). In addition, visitors may not be fully aware of evacuation procedures or even the potential for lahars if they are coming from areas with no history of lahars. The presence of public venues in the lahar-hazard zone, however, also presents an outreach opportunity for emergency managers to work with owners and employees of these public venues to educate local and tourist populations.

The number of public venues in lahar-prone areas of each community provides some insight about tourist locations but does not capture the range in magnitudes of tourist populations at these sites. Therefore, these counts should serve as starting points for discussion and further studies about high-occupancy public venues. An example of a high-occupancy public venue in the lahar-hazard zone is the Puyallup Fairgrounds in the City of Puyallup (fig. 1), where daily visitor attendance at the annual 17-day Puyallup Fair can exceed 100,000 people (Puyallup Fair \& Events Center, 2009) —more than the total number of residents in the lahar-hazard zone (table 1). Twenty-five percent of Fair attendees come from outside of the four counties (Puyallup Fair \& Events Center, 2009) and may not be well educated about Mount Rainier lahar hazards or prepared to react if a lahar occurred. Another example is Mount Rainier National Park (fig. 1), which attracts almost two million visitors each year (Driedger and Scott, 2008). With the limited time available to evacuate and the remoteness 
Table 4. Amount and percentage of public venues in the selected lahar-hazard zone of Mount Rainier, Washington.

\begin{tabular}{|c|c|c|c|c|c|c|c|c|c|c|}
\hline & \multicolumn{2}{|c|}{ All Four Counties } & \multicolumn{2}{|c|}{ King County } & \multicolumn{2}{|c|}{ Lewis County } & \multicolumn{2}{|c|}{ Pierce County } & \multicolumn{2}{|c|}{ Thurston County } \\
\hline & $\begin{array}{c}\text { Lahar- } \\
\text { Hazard } \\
\text { Zone }\end{array}$ & $\begin{array}{c}\text { Percentage of } \\
\text { Four-County } \\
\text { Total } \\
\end{array}$ & $\begin{array}{c}\text { Lahar- } \\
\text { Hazard } \\
\text { Zone }\end{array}$ & \begin{tabular}{|c|}
$\begin{array}{c}\text { Percentage } \\
\text { of County } \\
\text { Total }\end{array}$ \\
\end{tabular} & $\begin{array}{l}\text { Lahar- } \\
\text { Hazard } \\
\text { Zone } \\
\end{array}$ & \begin{tabular}{|c|}
$\begin{array}{c}\text { Percentage } \\
\text { of County } \\
\text { Total }\end{array}$ \\
\end{tabular} & $\begin{array}{l}\text { Lahar- } \\
\text { Hazard } \\
\text { Zone } \\
\end{array}$ & $\begin{array}{c}\text { Percentage } \\
\text { of County } \\
\text { Total } \\
\end{array}$ & $\begin{array}{l}\text { Lahar- } \\
\text { Hazard } \\
\text { Zone }\end{array}$ & $\begin{array}{c}\text { Percentage } \\
\text { of County } \\
\text { Total } \\
\end{array}$ \\
\hline Casinos & 1 & $4 \%$ & 0 & $0 \%$ & 0 & $0 \%$ & 1 & $20 \%$ & 0 & $0 \%$ \\
\hline Colleges and universities & 1 & $<1 \%$ & 0 & $0 \%$ & 0 & $0 \%$ & 1 & $1 \%$ & 0 & $0 \%$ \\
\hline Museums & 6 & $11 \%$ & 0 & $0 \%$ & 1 & $50 \%$ & 5 & $24 \%$ & 0 & $0 \%$ \\
\hline Overnight accommodations & 57 & $9 \%$ & 1 & $0 \%$ & 15 & $25 \%$ & 40 & $27 \%$ & 1 & $2 \%$ \\
\hline Fairgrounds, parks and zoos & 7 & $7 \%$ & 1 & $1 \%$ & 1 & $20 \%$ & 5 & $28 \%$ & 0 & $0 \%$ \\
\hline Religious organizations & 78 & $4 \%$ & 13 & $1 \%$ & 6 & $6 \%$ & 59 & $10 \%$ & 0 & $0 \%$ \\
\hline
\end{tabular}

of some lahar-prone areas, hikers and other outdoor recreationists will need to recognize natural cues indicative of an approaching flow and take protective actions without official technology-based warnings. The U.S. National Park Service provides visitors to Mount Rainier National Park (USA) with lahar-related information (for example, printed material, wayside displays, and trailhead signs) that explain what lahars are and what to do when flows are seen or lahar-related sounds are heard (Driedger and others, 2002).

\section{Tax Parcel Value}

In addition to employee distributions, another economic dataset used to characterize variations in community exposure to lahar hazards is tax parcel values (represented by land and content values expressed in 2008 U.S. dollars). Parcel values are useful for understanding the spatial distribution of people and community assets because (1) high parcel values indicate human occupation, while parcels with no or low value indicate less developed areas, and (2) communities rely on property taxes for local services, which are critical for their longevity and health. Typically, communities expect immediate disasterrelief aid from external sources, but long-term funds for the restoration of social services come from revenue generated by property taxes. If an extreme event destroys property, then land values and the community tax base are reduced. Decreases in tax base affect the provision of social services and hamper long-term disaster recovery. As social services decrease, so may populations if individuals seek out other communities that can provide needed services. The laharhazard zone contains parcel values assessed at approximately $\$ 8.8$ billion, representing 2 percent of the total parcel values in the four counties (table 2). More than $\$ 6$ billion of this parcel-value exposure is in Pierce County, which represents 11 percent of total parcel values in this county. The percentage of total parcel value in the lahar-hazard zone is low for the other three counties (for example, less than 1 percent in Thurston, 1 percent in King County, and 5 percent in Lewis County).

The amount (fig. 12A) and percentage (fig. 12B) of total parcel values in lahar-prone areas of each community varies significantly across the study area. The City of Puyallup has the highest amount of total parcel value in the lahar-hazard zone ( $\$ 1.6$ billion), and several communities (for example, Fife, Orting) have 100 percent of their tax base in the lahar-hazard zone. As with the land-use/land-cover and residential data, there are several areas with high amounts but relatively low percentages of parcel value in the lahar-hazard zone (for example, Auburn, Puyallup), while other areas have low amounts but high percentages of their parcel value in the zone (for example, Orting, South Prairie). Only the communities of Fife and Sumner are above third-quartile values in both the amount and percentage of parcel values in the lahar-hazard zone.

\section{Critical and Essential Facilities and Infrastructure}

Facilities considered critical for short-term response and essential for long-term community recovery were identified using NAICS codes in the InfoUSA Employer database. Critical facilities include those used for public safety purposes (civil-defense facilities, fire stations, national-security facilities, police stations, and radio and television stations), medical services (ambulances, hospitals, outpatient-care centers, and physician offices), and infrastructure maintenance (electric, public-works, natural-gas, waste-water, and water and sewer facilities). Critical facilities in the lahar-hazard zone of the four counties include fire stations (12), police stations (10), water and sewer facilities (9), and public-works facilities (5) 


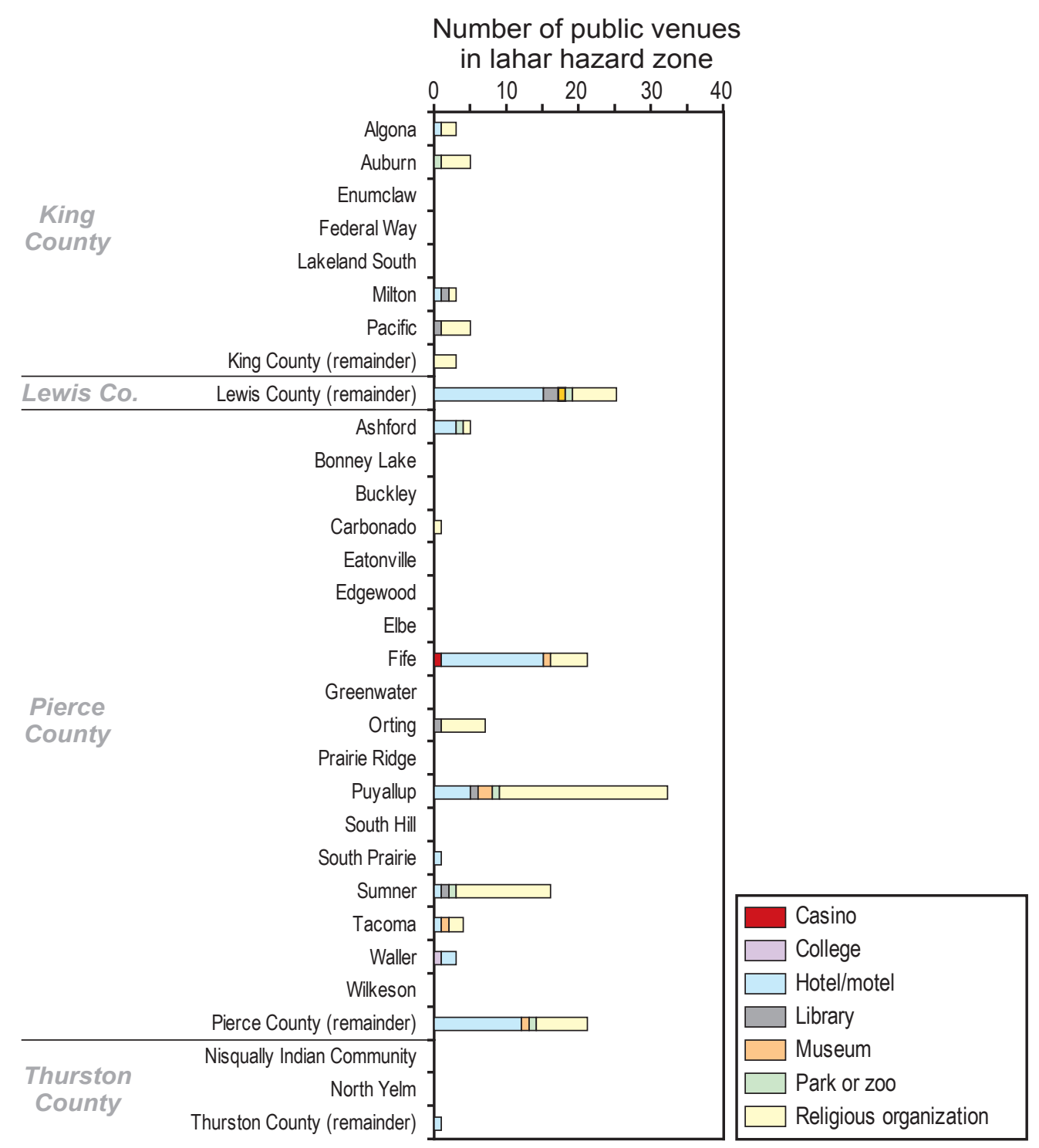

Figure 11. Number of public venues in the selected lahar-hazard zone for communities downstream of Mount Rainier.

(table 5). Essential facilities include those that provide for basic necessities (banks and credit unions, gas stations, and grocery stores) or serve government functions (courts and legal offices, government offices, international-affairs offices, and U.S. Post Offices). Long-term community recovery may also be hampered by the potential loss of the numerous essential facilities in the lahar-hazard zone, including doctor offices (91), government offices (47), banks and credit unions (40), grocery stores (23), gas stations (14), and U.S. Post Offices (12) (table 5).

In addition to direct impacts to facilities in the laharhazard zone, critical and essential facilities and the services they provide could be affected indirectly from breaks in regional infrastructure networks (such as, water, sewer, gas, electricity). For example, an overlay of the regional state-road, highway, and railroad network (Washington State Department of Transportation, 2007) on the lahar-hazard zone suggests that key transportation segments could be buried by future lahars (fig. 13). In the intermediate aftermath of a catastrophic lahar, transportation lines cut or buried by lahars would directly affect the movement of evacuees and disaster-relief aid (for example, food, medicine, fuel). Social services and critical facilities (for example, hospitals) may be operational after an event but inaccessible if roads to the facilities are closed because of lahar inundation. For example, access to emergency services (for example, hospitals) and residents' ability to get essential supplies were crippled when long spans of the Interstate 5 (I-5) highway (fig. 13) were closed for 4 days in the winter of 2008 by rain-related flooding (Ivanov and others, 2008). 


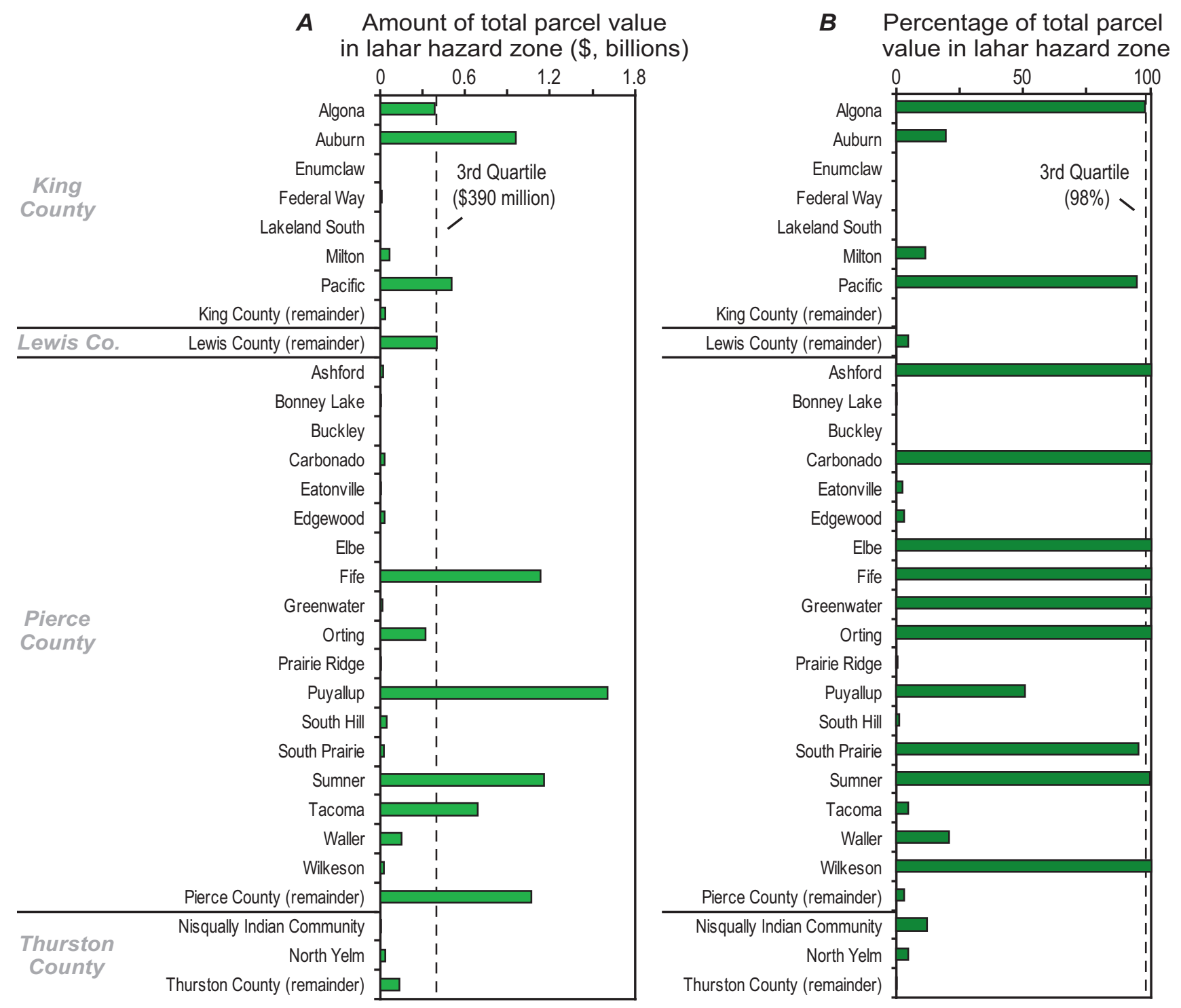

Figure 12. Amount $(A)$ and percentage $(B)$ of total parcel value in the selected lahar-hazard zone for communities downstream of Mount Rainier.

Road and rail closures from lahar inundation will also have indirect economic impacts for communities and the region because of dependence on certain critical corridors, such as the Port of Tacoma and the I-5 highway. The I-5 highway is the most heavily used north-south freight route in the U.S. Pacific Northwest. Economic impacts from the 4-day road closure in the 2008 flooding event were approximately $\$ 47$ million (Ivanov and others, 2008). The bulk of the losses from this storm were in freight-dependent industry sectors (for example, agribusiness, forest and wood products, construction, manufacturing, wholesale, and retail sectors), which are the dominant industries in lahar-prone areas (fig. 3 ). The Port of Tacoma also is vulnerable to future lahars, either from direct lahar impacts to terminals and container cranes or indirect impacts from the loss of nearby roads and railroads for shipping. The Port of Tacoma, the seventh largest container port in North America, relies heavily on I-5, State Road 509, and State Road 167 (fig. 13) for shipping cargo to inland destinations, and 70 percent of the Port's international import container cargo is transported via the nearby rail system. In 2008, the Port handled more than $\$ 35$ billion in foreign trade and $\$ 3$ billion in domestic trade (Port of Tacoma, 2009) — both of which would be severely affected if nearby roads and rail systems were buried in lahar deposits. Trade reductions due to damaged transportation infrastructure could lead to reductions in jobs (more than 116,000 jobs in 2004 in the State of Washington were related to Port of Tacoma activities) and State and local tax revenue (\$107.5 million in 2004 in tax revenue was related to the Port) (Martin Associates, 2005). 
Table 5. Amount and percentage of critical and essential facilities assets in the selected lahar-hazard zone of Mount Rainier, Washington.

\begin{tabular}{|c|c|c|c|c|c|c|c|c|c|c|}
\hline & \multicolumn{2}{|c|}{ All Four Counties } & \multicolumn{2}{|c|}{ King County } & \multicolumn{2}{|c|}{ Lewis County } & \multicolumn{2}{|c|}{ Pierce County } & \multicolumn{2}{|c|}{ Thurston County } \\
\hline & $\begin{array}{c}\text { Lahar- } \\
\text { Hazard } \\
\text { Zone }\end{array}$ & $\begin{array}{c}\text { Percentage of } \\
\text { Four-County } \\
\text { Total }\end{array}$ & $\begin{array}{c}\text { Lahar- } \\
\text { Hazard } \\
\text { Zone }\end{array}$ & $\begin{array}{c}\text { Percentage } \\
\text { of County } \\
\text { Total }\end{array}$ & $\begin{array}{c}\text { Lahar- } \\
\text { Hazard } \\
\text { Zone }\end{array}$ & $\begin{array}{c}\text { Percentage } \\
\text { of County } \\
\text { Total }\end{array}$ & $\begin{array}{l}\text { Lahar- } \\
\text { Hazard } \\
\text { Zone }\end{array}$ & $\begin{array}{c}\text { Percentage } \\
\text { of County } \\
\text { Total }\end{array}$ & $\begin{array}{c}\text { Lahar- } \\
\text { Hazard } \\
\text { Zone }\end{array}$ & $\begin{array}{c}\text { Percentage } \\
\text { of County } \\
\text { Total } \\
\end{array}$ \\
\hline \multicolumn{11}{|l|}{ Critical Facilities } \\
\hline Civil defense facilities & 0 & $0 \%$ & 0 & $0 \%$ & 0 & $0 \%$ & 0 & $0 \%$ & 0 & $0 \%$ \\
\hline Fire stations & 12 & $11 \%$ & 1 & $2 \%$ & 3 & $27 \%$ & 8 & $22 \%$ & 0 & $0 \%$ \\
\hline Police stations & 10 & $7 \%$ & 2 & $3 \%$ & 1 & $10 \%$ & 7 & $16 \%$ & 0 & $0 \%$ \\
\hline Ambulance services & 2 & $11 \%$ & 0 & $0 \%$ & 0 & $0 \%$ & 2 & $40 \%$ & 0 & $0 \%$ \\
\hline Hospitals & 0 & $0 \%$ & 0 & $0 \%$ & 0 & $0 \%$ & 0 & $0 \%$ & 0 & $0 \%$ \\
\hline Outpatient-care facilities & 4 & $1 \%$ & 0 & $0 \%$ & 1 & $20 \%$ & 3 & $5 \%$ & 0 & $0 \%$ \\
\hline Radio and TV facilities & 1 & $1 \%$ & 0 & $0 \%$ & 0 & $0 \%$ & 1 & $9 \%$ & 0 & $0 \%$ \\
\hline Water and sewage facilities & 9 & $9 \%$ & 0 & $0 \%$ & 1 & $17 \%$ & 8 & $30 \%$ & 0 & $0 \%$ \\
\hline \multicolumn{11}{|l|}{ Essential facilities } \\
\hline Banks and credit unions & 40 & $4 \%$ & 2 & $0 \%$ & 0 & $0 \%$ & 38 & $14 \%$ & 0 & $0 \%$ \\
\hline Courts and legal offices & 8 & $8 \%$ & 0 & $0 \%$ & 0 & $0 \%$ & 8 & $23 \%$ & 0 & $0 \%$ \\
\hline Gas stations & 14 & $4 \%$ & 1 & $0 \%$ & 1 & $17 \%$ & 11 & $15 \%$ & 1 & $4 \%$ \\
\hline Doctor offices & 91 & $2 \%$ & 4 & $0 \%$ & 1 & $1 \%$ & 86 & $9 \%$ & 0 & $0 \%$ \\
\hline Government offices & 47 & $4 \%$ & 2 & $0 \%$ & 2 & $3 \%$ & 42 & $17 \%$ & 1 & $0 \%$ \\
\hline
\end{tabular}

The potential impact of future lahar flows from Mount Rainier will vary depending on where the lahars originate. Flows confined to the Cowlitz and White Rivers (fig. 13) could impact rural communities but may not impact regional roads. Flows confined to the Nisqually River valley that carry beyond the Alder Reservoir could bisect relatively small segments of the I-5 highway and State Road 507. The largest potential impacts could be associated with lahar flows coming down the Puyallup and Carbon River valleys, as flows could bisect I-5 and also impact the Port of Tacoma, creating further direct economic losses to Pierce County and indirect losses for the region. These observations are based only on the spatial coincidence of lahar-hazard zones and regional road networks; the integrity and resilience of the transportation network after a lahar are areas ripe for further research.

\section{Composite Indices of Community Exposure}

We developed two composite indices to compare community exposure from lahars for the 31 geographic units (18 incorporated cities, 9 unincorporated census-designated places, and the remaining unincorporated land in the 4 counties). The indices were derived for each geographic unit from the amounts and percentages of six variables - developed lands, residents, employees, public venues, dependent-population facilities, and total tax-parcel values. Each composite index was created by normalizing values in the six categories to the maximum value found within that category. Normalizing data to maximum values creates a common data range of zero to one for all six categories and is a simple approach 


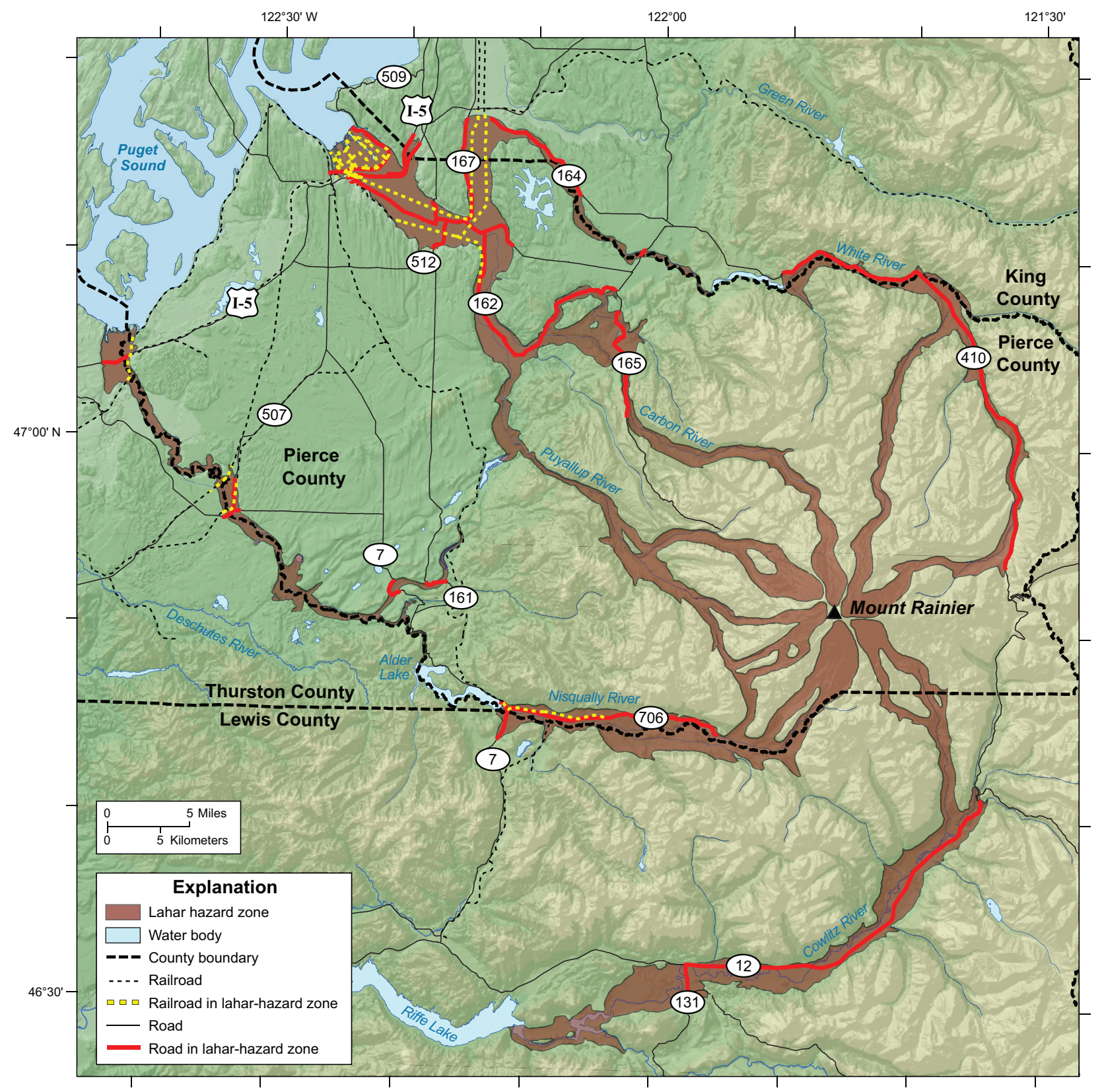

Figure 13. Map of roads and railroads in the selected lahar-hazard zone (Hoblitt and others, 1998; Schilling and others, 2008) on and near Mount Rainier, Washington.

for comparing disparate datasets. The six normalized values in each community were added, resulting in a score that ranged between zero and six for each of the 31 geographic units (table 6). Each geographic unit has two composite indicesone summarizing the number of assets in lahar-prone areas and another summarizing the percentage of total community assets in lahar-prone areas. The two indices are unitless, relative values to help us compare the 31 geographic units, but they have no absolute meaning for a community.

Table 6 summarizes the composite amount and percentage indices (each with a range from 0 to 6 ) for the 31 areas, where higher values indicate higher amounts or percentages.
For example, the City of Puyallup has the highest composite amount value (5.7), indicating that this community consistently has one of the highest amounts of assets in the laharhazard zone. The communities of Carbonado, Fife, and Orting have the maximum composite percentage value (6.0), indicating they have the highest percentage of assets in the laharhazard zone for each of the six categories. Some communities (for example, Tacoma, the unincorporated areas of Pierce County) have higher relative amount values than percentages, whereas others (for example, Algona, Pacific, Ashford, South Prairie, and Wilkeson) have higher relative percentages values. Few towns have many assets in the selected lahar-hazard 


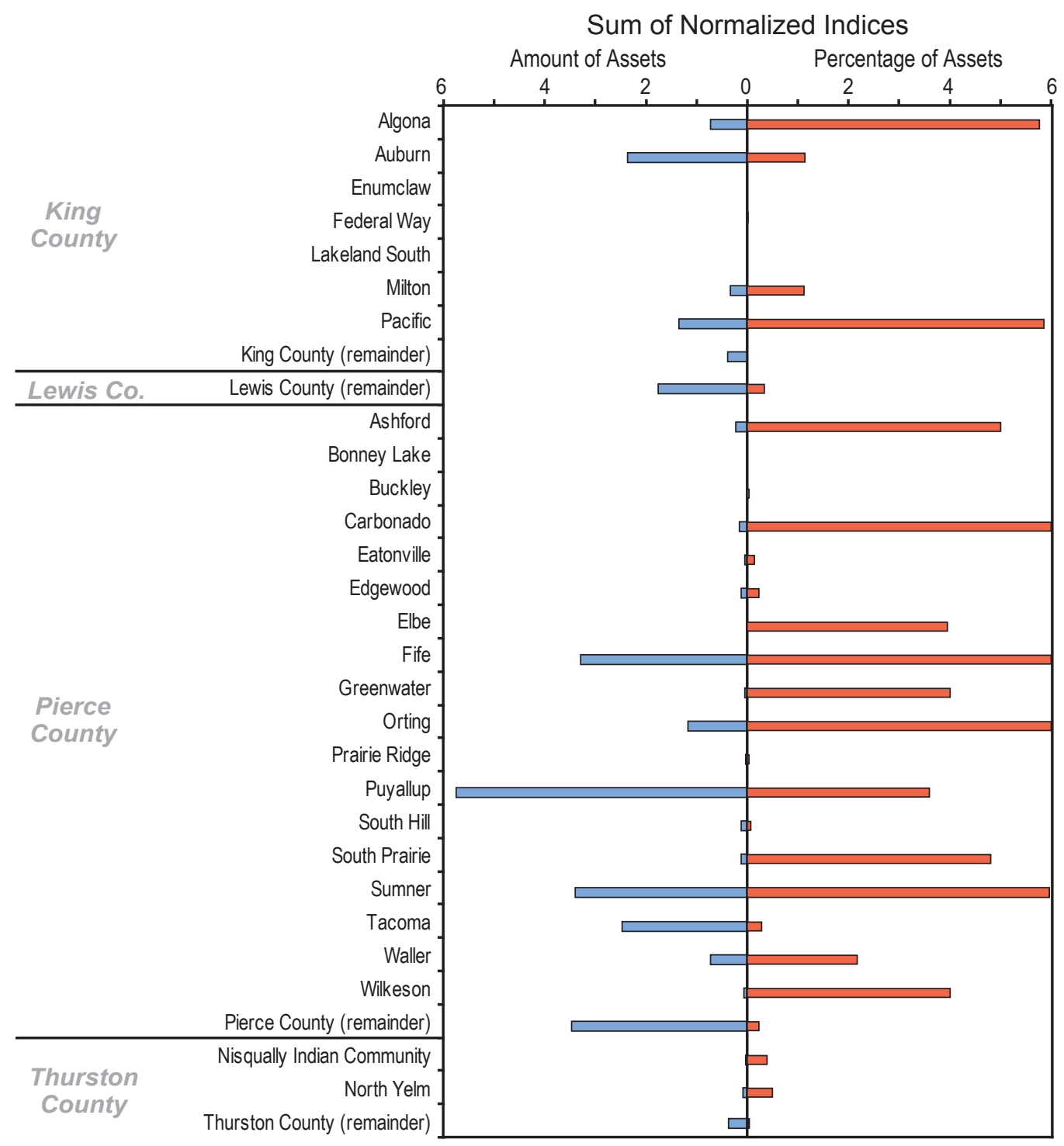

Figure 14. Comparison of normalized indices for the amount and percentage of community assets (developed land, residents, employees, public venues, dependent-population facilities, and parcel value) in lahar-prone areas for communities that include land in the selected Mount Rainier lahar-hazard zone.

zone (for example, Puyallup, Fife, and Sumner) but there are several towns with high percentages of their assets in this area. Regardless of size, towns such as Algona, Ashford, Greenwater, Orting, and Pacific may experience similar relative impacts.

Figure 14 provides the same information as table 6, but in graphic form to help the reader better visualize geographic variations in composite scores within the study area. Although the composite amount and percentage indices share a common data range of 0 to 6 , the amount graph is graphically reversed in figure 14 to facilitate easier comparisons of the two values in individual communities.

We calculated a final score for each of the 31 geographic units by normalizing the amount and percentage indices to maximum values (yielding a common data range between zero and one for the two indices) and then adding the two indices, resulting in values ranging between zero and two (fig. 15). Normalizing the two indices before adding them is needed to eliminate weighting bias between the indices; this bias can occur because of differences in the distribution of values within each index. Communities with the highest final scores have the highest numbers and percentages of people and assets in the lahar-hazard zone. Although not observed, a final score of two would indicate that a community always had the highest number and percentage of people and assets in the laharhazard zone for each of the six categories.

This approach results in the cities of Puyallup, Sumner, and Fife having the highest relative exposure to lahars, each 
Table 6. Composite amount and percentage values for communities in the selected lahar-hazard zone of Mount Rainier, Washington [see text for explanation on derivation of values].

\begin{tabular}{c|l|l}
\hline $\begin{array}{c}\text { Range of } \\
\text { Normalized } \\
\text { Indices }\end{array}$ & Amount of Assets & Percentage of Assets \\
\hline & & Algona \\
& & Ashford \\
& & Carbonado (6.0) \\
5.0 to 6.0 & Puyallup (5.7) & Fife (6.0) \\
& & Orting (6.0) \\
& & Pacific \\
& & Sumner (6.0) \\
\hline
\end{tabular}

\begin{tabular}{|c|c|c|}
\hline 4.0 to 4.9 & & $\begin{array}{l}\text { Greenwater } \\
\text { South Prairie }\end{array}$ \\
\hline 3.0 to 3.9 & $\begin{array}{l}\text { Fife } \\
\text { Sumner } \\
\text { Pierce County } \\
\quad \text { (remainder) }\end{array}$ & $\begin{array}{l}\text { Elbe } \\
\text { Puyallup }\end{array}$ \\
\hline 2.0 to 2.9 & $\begin{array}{l}\text { Auburn } \\
\text { Tacoma }\end{array}$ & Waller \\
\hline 1.0 to 1.9 & $\begin{array}{l}\text { Orting } \\
\text { Pacific } \\
\text { Lewis County } \\
\quad \text { (remainder) }\end{array}$ & $\begin{array}{l}\text { Auburn } \\
\text { Milton }\end{array}$ \\
\hline 0 to 0.9 & $\begin{array}{l}\text { Algona } \\
\text { Ashford } \\
\text { Bonney Lake } \\
\text { Buckley } \\
\text { Carbonado } \\
\text { Eatonville } \\
\text { Edgewood } \\
\text { Elbe } \\
\text { Enumclaw } \\
\text { Federal Way } \\
\text { Greenwater } \\
\text { King County (remainder) } \\
\text { Lakeland South } \\
\text { Milton } \\
\text { Nisqually Indian Community } \\
\text { North Yelm } \\
\text { Prairie Ridge } \\
\text { South Hill } \\
\text { South Prairie } \\
\text { Thurston County (remainder) } \\
\text { Waller } \\
\text { Wilkeson }\end{array}$ & $\begin{array}{l}\text { Bonney Lake } \\
\text { Buckley } \\
\text { Eatonville } \\
\text { Edgewood } \\
\text { Enumclaw } \\
\text { Federal Way } \\
\text { King County } \\
\text { (remainder) } \\
\text { Lakeland South } \\
\text { Lewis County } \\
\text { (remainder) } \\
\text { Nisqually Indian } \\
\text { Community } \\
\text { North Yelm } \\
\text { Pierce County } \\
\text { (remainder) } \\
\text { Prairie Ridge } \\
\text { Tacoma } \\
\text { Thurston County } \\
\text { (remainder) } \\
\text { South Hill }\end{array}$ \\
\hline
\end{tabular}

with a combined value of approximately 1.6. Puyallup's high exposure is due to high numbers of assets in lahar-prone areas, whereas the vulnerability of Sumner and Fife has more to do with the high percentage of their assets in lahar-prone areas. The next nine communities in this relative ranking (Pacific to Elbe in figure 15) have high relative exposure to lahar hazards, but this is primarily because of high percentages, not amounts, of people and assets in the hazard zone. Although these communities have varying numbers of people and amounts of assets in the lahar-hazard zone, the impacts on these communities may be similar because of the similar percentages of people and assets in the lahar-hazard zone. The third group includes the medium to large communities of Auburn, Waller, and Tacoma and the remaining unincorporated land of Pierce and Lewis Counties. In this third group, the areas have relatively low composite values (approximately 0.5 ) that are largely the result of smaller amounts of assets in lahar-prone areas. The fourth group includes the remaining 14 communities, which have very low composite values (approximately 0.2 and less).

\section{Conclusions}

Large lahars associated with Mount Rainier that reach the Puget Sound lowlands are credible threats to downstream communities. Officials need to better understand how communities are vulnerable to lahars if they are to mitigate potential impacts and prepare at-risk populations. The lahar-hazard zone that is based on the Electron Mudflow from Mount Rainier, Washington, contains 78,049 residents, 59,678 employees, and numerous public venues and dependent-population facilities. Twenty-one percent of the exposed residential population lives outside of the 18 incorporated cities and 9 unincorporated towns, suggesting a need for lahar awareness programs in rural areas. Targeted education may also be warranted for the high percentage of renter-occupied households, because renters are likely to have less access and sustained exposure to risk education and evacuation training than long-term homeowners. Sustained lahar risk and evacuation education is also important at several high-occupancy public venues in the lahar-hazard zone (for example, Puyallup Fairgrounds, Mount Rainier National Park), where daily visitor attendance at these sites can be greater than exposure estimates for residents and employees only.

Communities vary in the types of people that are in lahar-prone areas. While the communities of Puyallup, Fife, and Sumner have highly mixed populations, the exposed populations in other communities are dominated by certain types, such as residents (for example, Auburn), employees (for example, Tacoma), and tourists at public venues (for example, unincorporated portions of Lewis County). Education efforts will vary for these different audiences. Sustained education and evacuation training for local residents could be implemented through existing social networks (for example, 


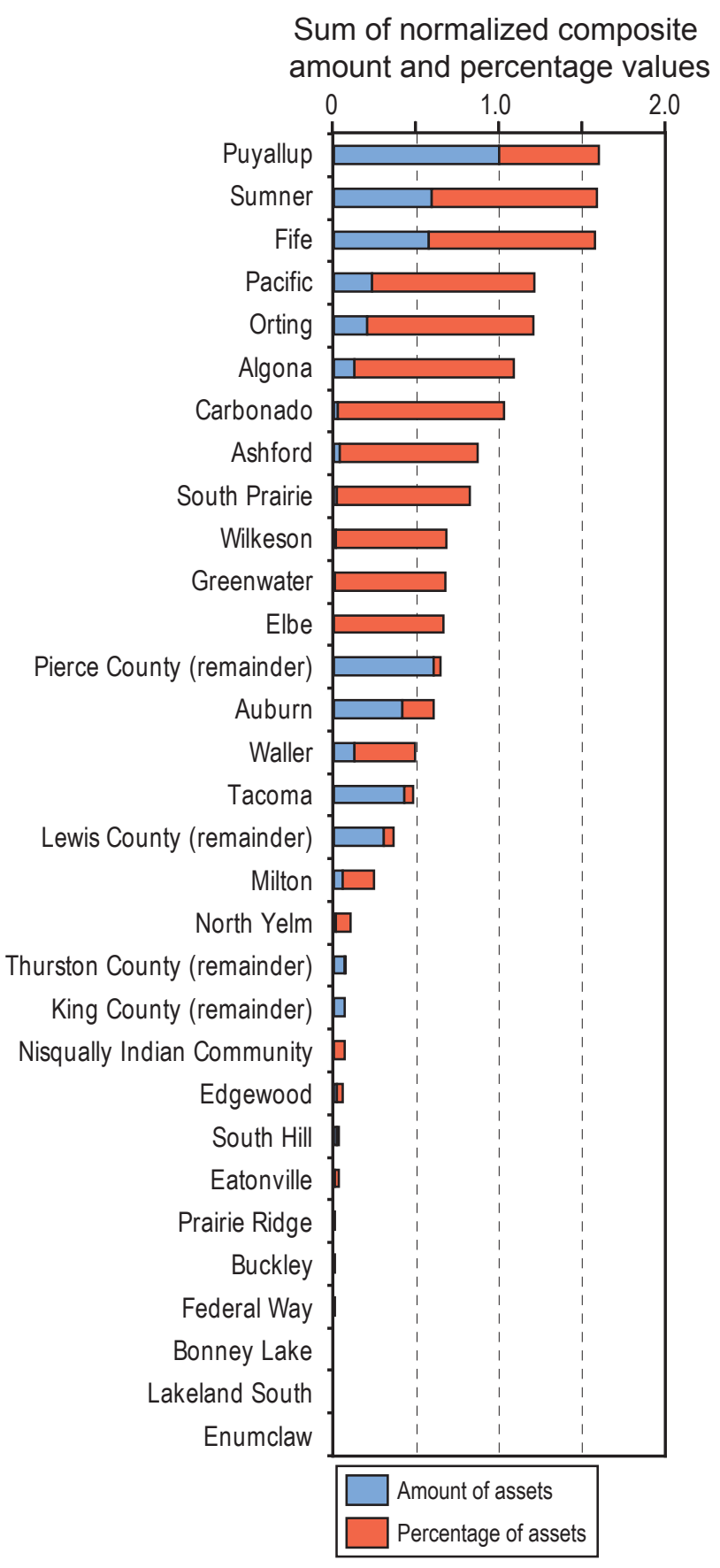

Figure 15. Sum of normalized amount and percentage indices for relative exposure to lahar hazard for communities with land in the selected Mount Rainier lahar-hazard zone. neighborhood groups, church groups, parent-teacher associations, and chambers of commerce) and can capitalize on residents' familiarity with their physical surroundings. Sustained education and training also are possible with employees, although they differ from residents in that they may not be familiar with the surrounding area or with lahar hazards and may have limited access to information if they rely on business owners for educational materials. For industry-related businesses (for example, warehousing, manufacturing, and construction), education efforts ideally would address the potential for hazardous materials or equipment (for example, power lines and cranes) on the premises to obstruct or constrain an individual's ability to evacuate before an imminent lahar. For businesses with a significant customer presence (for example, retail trade), employees would ideally be trained not only in evacuation procedures for their own safety but also in crowd control and evacuation leadership, as they will need to guide tourists who are likely unaware of lahar risks. Unlike efforts for residents and employees, education efforts for tourists are typically limited to static information available at public venues and evacuation procedures that emphasize easily identifiable physical landmarks. Although tourists at public venues (for example, fairgrounds, and parks) likely make up the highest number of people in the lahar-hazard zone, they are also likely to be the hardest to reach. Sustained education efforts are not possible with one-time visitors.

Community exposure to lahars associated with Mount Rainier varies considerably among 27 communities and four counties - some may experience great losses that nevertheless affect a small portion of their community and others may experience relatively small losses that devastate them. The city of Puyallup has the highest numbers and the communities of Carbonado, Fire, Orting, Pacific, and Sumner have the highest percentages of people and assets in the lahar-hazard zone. Communities with more people and assets in the lahar-hazard zone may end up having higher losses from a lahar, but communities with high percentages of their people and assets in the lahar-hazard zones may experience greater relative impacts and social disruption and have fewer internal resources available during recovery. In general, the cities of Puyallup, Sumner, and Fife have the highest community exposure to lahar hazards, on the basis of composite indices that compare the relative number and percentage of people and certain assets in the lahar-hazard zone.

Economic impacts from lahars may be greatest from indirect effects due to the loss of infrastructure. Approximately 60,000 people work in the lahar-hazard zone, which represents only 4 percent of all employees in the four counties; county workforce exposure ranges from less than 1 percent of employees in King County to 18 percent in Pierce County. Total tax-parcel value in the lahar-hazard zone is $\$ 8.8$ billion, which accounts for 2 percent of the total parcel values in the four counties and ranges from less than 1 percent in Thurston County to 11 percent in Pierce County. Although the percentages of employees and of parcel values in the laharhazard zone are low, indirect economic impacts of lahars to 
businesses (for example, Port of Tacoma) and counties may be high because of the reliance on key road and railroad corridors (fig. 13). Many of the businesses in the lahar-hazard zone are in sectors that rely on functioning road and rail networks, such as manufacturing, transportation and warehousing, wholesale trade, and construction (fig. 9). The loss of these transportation networks, as well as key critical facilities (for example, fire and police stations) also could hamper short-term response and long-term recovery efforts.

This report focuses on the lahar-prone landscapes in King, Lewis, Pierce, and Thurston Counties in Washington and was developed to support collaboration between the Washington Military Department Emergency Management Division and the U.S. Geological Survey that focuses on improving our understanding of community vulnerability to volcanic hazards. Information presented in this report will support emergency, land use, and resource managers in their efforts to identify where additional preparedness, mitigation, recovery planning, and outreach activities may be needed within communities and economic sectors to manage risks associated with Mount Rainier lahars.

\section{Acknowledgments}

This study was supported by the U.S. Geological Survey (USGS) Geographic Analysis and Monitoring (GAM) program. Portions of the analysis reported in this report were developed originally for publication in the Journal of Volcanology and Geothermal Research. We thank Dave Nelson of the State of Washington Emergency Management Division (WEMD) for setting the stage for this collaborative project between the USGS and the WEMD. Susan Benjamin, Carolyn Driedger, Dave Ramsey, and Mara Tongue of the USGS and John Schelling of the WEMD gave insightful reviews of the manuscript.

\section{References Cited}

Alwang, J., Siegel, P., and Jorgensen, S., 2001, Vulnerability - a view from different disciplines: Washington, D.C., The World Bank, Social Protection Discussion Paper Series No. 0115,42 p.

Aster, R., Bergantz, G., Carn, S., Serafino, G., Wilson, J., Yepes, H., and White, K., 2007, Review of the United States Geological Survey Volcano Hazards Program: Report of the American Association for the Advancement of Science Research Competitiveness Program, 35 p. [http://volcanoes. usgs.gov/publications/pdf/aaas2007.pdf, last accessed March 3, 2009].
Balaban, V., 2006, Psychological assessment of children in disasters and emergencies: Disasters, v. 30, no. 2, p. 178-198.

Burby, R., Steinberg, L., and Basolo, V., 2003, The tenure trap - the vulnerability of renters to joint natural and technological disasters: Urban Affairs Review, v. 39, no. 1, p. $32-58$.

Bureau of Labor Statistics, U.S. Department of Labor, 2007, United States economy at a glance: [http://www.bls.gov/ eag/eag.us.htm, last accessed July 1, 2008].

Cutter, S., Boruff, B., and Shirley, W., 2003, Social vulnerability to environmental hazards: Social Science Quarterly, v. 84, no. 2, p. 242-261.

Driedger, C., and Scott, K., 2002, Mount Rainier-learning to live with volcanic risk: U.S. Geological Survey Fact Sheet 034-02, 4 p. [http://pubs.usgs.gov/fs/2008/3062/].

Driedger, C., and Scott, W., 2008, Mount Rainier-living safely with a volcano in your background: U.S. Geological Survey Fact Sheet 2008-3062, 4 p.

Driedger, C., Wolfe, E., and Scott, K., 1998, Living with a volcano in your back yard - a prepared presentation for use by public officials and educators: U.S. Geological Survey Open-File Report 1998-519-A [http://pubs.er.usgs.gov/ usgspubs/ofr/ofr98519A, last accessed March 3, 2009].

Driedger, C., Stout, T., and Hawk, J., 2002, The mountain is a volcano! addressing geohazards at Mount Rainier: Ranger, The Journal of the Association of National Park Rangers, v. 18 , no. 2, p. $14-15$.

Driedger, C., Doherty, A., and Dixon, C., 2005, Living with a volcano in your backyard - an educator's guide with emphasis on Mount Rainier: U.S. Geological Survey and National Park Service, General Interest Product 19.

Enarson, E., and Morrow, B., 1998, The gendered terrain of disaster: Westport, Connecticut, Praeger, 275 p.

Federal Emergency Management Agency, 2001, State and local mitigation planning how-to guide No. 2-understanding your risks: Federal Emergency Management Agency Report no. 386-2 [http://www.fema.gov/library/viewRecord. do? id=1880, last accessed August 21, 2007].

Finn, C.A., Sisson, T.W., and Deszcz-Pan, M., 2001, Aerogeophysical measeurements of collapse-prone hydrothermally altered zones at Mount Rainier volcano: Nature, v. 409, p. 600-603.

Hoblitt, R., Walder, J., Driedger, C., Scott, K., Pringle, P., and Vallance, J., 1998, Volcano hazards from Mount Rainier, Washington, revised 1998: U.S. Geological Survey OpenFile Report 98-428, 11 p. 
Homer, C., Huang, C., Yang, L., Wylie, B., and Coan, M., 2004, Development of a 2001 National Landcover Database for the United States: Photogrammetric Engineering and Remote Sensing, v. 70, no. 7, p. 829-840.

InfoUSA, 2008, Employer database: online dataset [http:// www.infousagov.com/employer.asp, last accessed November 20, 2008].

Ivanov, B., Xu, G., Buell, T., Moore, D., Austin, B., and Wang, Y., 2008, Storm related closures of I-5 and I-90 - freight transportation economic impact assessment report, winter 2007-2008: Washington State Department of Transportation Report WA-RD 708.1, 34 p.

Laska, S., and Morrow, B., 2007, Social vulnerabilities and Hurricane Katrina - an unnatural disaster in New Orleans: Marine Technology Society Journal, v. 40, no. 4, p. 16-26.

Martin Associates, 2005, The economic impact of the Port of Tacoma: Report prepared for The Port of Tacoma, $42 \mathrm{p}$.

McGuire, L., Ford, E., and Okoro, C., 2007, Natural disasters and older US adults with disabilities - implications for evacuation: Disasters, v. 31, no. 1, p. 49-56.

Mileti, D., 1999. Disasters by design - a reassessment of natural hazards in the United States: Washington, D.C., Joseph Henry Press, 376 p.

Morrow, B., 1999, Identifying and mapping community vulnerability: Disasters, v. 23, no. 1, p. 1-18.

National Oceanic and Atmospheric Administration Coastal Services Center, 2007, Land cover analysis - C-CAP classification scheme: [http:/www.csc.noaa.gov/crs/lca/tech_cls. html, last accessed March 3, 2009].

Ngo, E., 2003, When disasters and age collide_reviewing vulnerability of the elderly: Natural Hazards Review, v. 2, no. 2 , p. $80-89$.

Office of Financial Management, 2009, GIS data layers for Washington State: Online datasets [http://www.ofm.wa.gov/ geographic/00tiger.asp, last accessed May 1, 2009].

Pelling, M., 2002, Assessing urban vulnerability and social adaptation to risk: International Development Planning Review, v. 24, no.1, p. 59-76.

Pierce County Department of Emergency Management, 2008, Mount Rainier volcanic hazards response plan [http://www. co.pierce.wa.us/pc/Abtus/ourorg/dem/EMDiv/Mt\%20 Rainier\%20VHRP.htm, last accessed March 3, 2009].

Pierce County GIS Data Express, 2009, Volcanic travel of time data: online [http://yakima.co.pierce.wa.us/geodataexpress/ main.html, last accessed May 1, 2009].
Pierson, T., 1998, An empirical method for estimating travel times for wet volcanic mass flows: Bulletin of Volcanology, v. 60 , p. $98-109$.

Polsky, C., Neff, R., and Yarnal, B., 2007, Building comparable global change vulnerability assessments - the vulnerability scoping diagram: Global Environmental Change, v. 17, p. $472-485$.

Port of Tacoma, 2009, Port of Tacoma - about us, [http:// www.portoftacoma.com/Page.aspx?nid=2, last accessed June 11, 2009].

Puyallup Fair \& Events Center, 2009, Attendance and demographics: online dataset [http://www.thefair.com/ sponsorship/attendance_demographics.php, last accessed May 1, 2009].

Schilling, S., Doelger, S., Hoblitt, R., Walder, J., Driedger, C., Scott, K., Pringle, P., and Vallance, J., 2008, Digital data for volcano hazards from Mount Rainier, Washington, revised 1998: U.S. Geological Survey Open-File Report 2007-1220 [http://pubs.usgs.gov/of/2007/1220/, last accessed March 3, 2009].

Scott, K.M., and Vallance, J.W., 1995, Debris flow, debris avalanche, and flood hazards at and downstream from Mount Rainier, Washington: U.S. Geological Survey Hydrologic Investigations Atlas HA-729, 2 sheets, scale 1:100,000, 9 p.

Sisson, T., and Vallance, J., 2009, Frequent eruptions of Mount Rainier over the last 2,600 years: Bulletin of Volcanology, v. 71 , no. 6 , p. 595-618.

Sisson, T., Vallance, J., and Pringle, P., 2001, Progress made in understanding Mount Rainier's hazards, Eos (American Geophysical Union Transactions), v. 82, no. 9, p. 113, 118-120.

Turner, B.L., Kasperson, R.E., Matson, P.A., McCarthy, J.L., Corell, R.W., Christensen, L., Eckley, N., Kasperson, J.X., Luers, A., Martello, M.L., Polsky, C., Pulsipher, A., and Schiller, A., 2003, A framework for vulnerability analysis in sustainability science: Proceedings of the National Academy of Sciences, v. 100, no. 14, p. 8074-8079.

U.S. Census Bureau, 2008, Census 2000: Census 2000 Gateway. [http://www.census.gov/main/www/cen2000.html, last accessed March 3, 2009].

Vallance, J., Cunico, M., and Schilling, S., 2003, Debris-flow hazards caused by hydrologic events at Mount Rainier, Washington: U.S. Geological Survey Open-File Report 2003-368 [http://geopubs.wr.usgs.gov/open-file/of03-368/ last accessed March 3, 2009].

Voight, B., 1990, The 1985 Nevado del Ruiz volcano catastrophe: anatomy and retrospection. Journal of Volcanology and Geothermal Research, 44: 349-386 
Walder, J., and Driedger, C., 1994, Geomorphic change caused by outburst floods and debris flows at Mount Rainier, Washington, with emphasis on Tahoma Creek valley: U.S. Geological Survey Water-Resources Investigations Report 93-4093, $93 \mathrm{p}$.

Washington State Department of Transportation, 2007, State routes of Washington State: scale 1:24,000 [http://www. wsdot.wa.gov/mapsdata/geodatacatalog/maps/24k/dot_ cartog/sr24k.htm].

Wisner, B., Blaikie, P., Cannon, T., and Davis, I., 2004, At risk - natural hazards, people's vulnerability and disasters,2nd ed.: New York, Routledge, 471 p.

Witham, C., 2005. Volcanic disasters and incidents - a new database: Journal of Volcanology and Geothermal Research, v. 148, p. 191-233.

Wood, N., 2007, Variations in city exposure and sensitivity to tsunami hazards in Oregon: U.S. Geological Survey Scientific Investigations Report 2007-5283, 37 p.

Wood, N., 2009, Tsunami exposure estimation with land-cover data-Oregon and the Cascadia subduction zone: Applied Geography, v. 29, p. 158-170.

Zar, J., 1984, Biostatistical analysis (2nd ed.): Englewood, New Jersey, Prentice Hall, 718 p. 
Produced in the Western Region, Menlo Park, California Manuscript approved for publication, September 16, 2009 Edited by Peter Stauffer

Layout by David R. Jones 

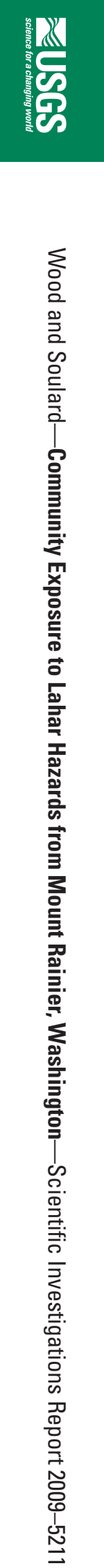